\title{
KE STAVU POZNÁNÍ STAVEBNÍCH DĚJIN BÝVALÉHO KLÁŠTERA PREMONSTRÁTEK ROSA COELI V DOLNÍCH KOUNICÍCH. NÁLEZ ROMÁNSKÉHO OBYTNÉHO OBJEKTU POD STAVBOU BAROKNÍHO KONVENTU
}

\author{
DAVID MERTA - MAREK PEŠKA
}

\begin{abstract}
Př́spěvek informuje o výsledcich záchranného archeologického výzkumu v areálu někdejšího kláštera premonstrátek $v$ Dolních Kounicich, který založil v roce 1181 moravský šlechtic Vilém z Pulina. Nejvýznamnějšim výsledkem výzkumu, probihajiciho v letech 2012 až 2013, bylo odkrytí románské (závèr 12. stoleti) jednotraktové budovy o rozměrech $18,6 \times 8,6 \mathrm{~m}$, situované severnè od gotické patrové kvadratury pod dnešnim barokním konventem. Objekt byl podsklepen a nenavazovaly na něj žádné dalši stavby. V rámci jeho stavebního vývoje bylo identifikováno celkem pět stavebnich fází a jeho zánik lze spojit $s$ výstavbou barokního konventu v závéru 17. století. Dle autorů nemusel být primárné konventní stavbou, ale lze jej s jistou opatrností považovat za sídlo Viléma z Pulína darované premonstrátkám snad i spolu se staršim vlastnickým kostelem.
\end{abstract}

Klíčová slova: raný středověk - vrcholný středověk - klášter-premonstrátky-palác-šlechtické sídlo.

The State of Knowledge of the Building History of the Rosa Coeli Premonstratensian Convent in Dolni Kounice. The Find of a Romanesque Residential Feature under the Baroque Convent

\begin{abstract}
This contribution brings information about the results of rescue archaeological research in the complex of the former Premonstratensian convent in Dolni Kounice, established by Moravian nobleman Vilém of Pulin in 1181. The most important outcome of the research that took place in 2012-2013 was the unearthing of a Romanesque (late 12th century) single-wing building of $18.6 \times 8.6 \mathrm{~m}$ situated north of the Gothic one-floor quadrature, under the present baroque convent. The construction had a cellar and was not adjoined by any other buildings. Five construction phases have been identified within its building development; its decline was probably associated with the construction of the baroque convent in the late 17 th century. The authors believe that it was not primarily a convent-type building but could be considered the seat of Vilém of Pulin made over to the Premonstratensians, possibly together with an older affiliated church.
\end{abstract}

Key words: early Middle Ages - high Middle Ages - convent - Premonstratensians - palace - aristocratic seat.

Někdejší klášter premonstrátek Rosa Coeli stojí na pravobřeží řeky Jihlavy při jižním okraji městečka Dolní Kounice. Z klášterního komplexu se dochovaly obvodové zdi kostela, patrový ambit a tzv. barokní konvent. Zaniklý areál je dosud ohrazen kamennou zdí s gotickou bránou, která se otevírá $\mathrm{k}$ městečku. V západní části areálu se nachází několik staveb, v nichž lze rozpoznat pozůstatky hospodářského dvora. Na severu areál končí u mlýnského náhonu, jehož původ je zřejmě středověký. Na jižní straně se terén zvedá k návrší, na němž stojí klášterní hrad (obr. 1). ${ }^{1}$

V letech 2012 a 2013 se uskutečnil v prostorách barokního konventu záchranný archeologický výzkum, který přinesl nová zjištění ke středověkým stavebním dějinám kláštera. Výsledky výzkumu jsou shrnuty v předloženém textu, jehož cílem je také představit úvahu o nové koncepci nejstarších stavebních dějin konventu.

1 Topografii klášterního areálu a jeho okolí podává plán z roku 1699, kde je zachycen konvent, hospodářské zázemí včetně mlýna a hrad stojící nad klášterem. 


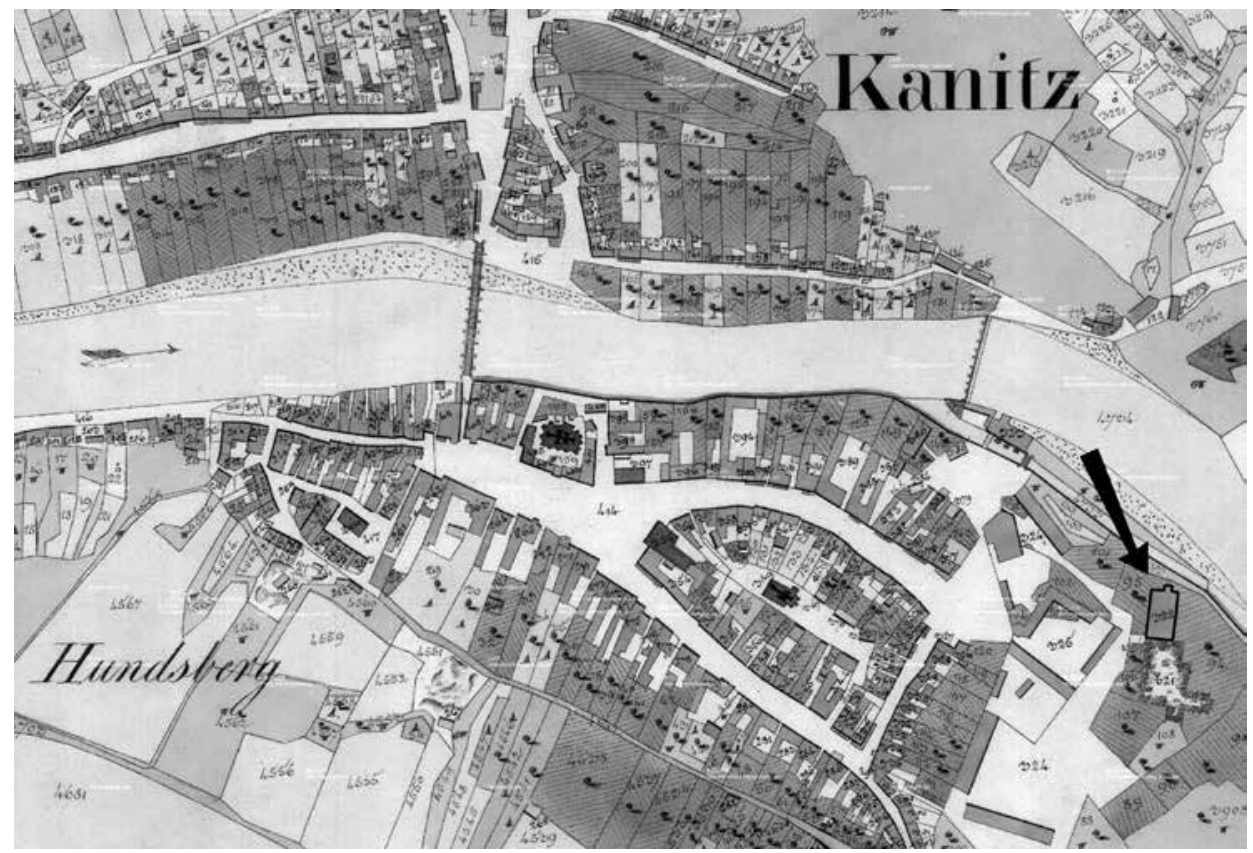

Obr. 1. Dolní Kounice, okr. Brno-venkov. Areál kláštera na plánu stabilního katastru s vyznačením barokního konventu. Archiv Archaia Brno, o.p.s.

Abb. 1. Dolní Kounice, Bez. Brno-Land. Areal des Kloster auf dem Plan des stabilen Katasters mit eingezeichnetem Barockkonvent. Archiv Archaia Brno, o.p.s.

\section{Historický exkurz}

Podle kronikáře Jarlocha založil klášter Rosa Coeli v Dolních Kounicích v roce 1181 Vilém z Pulína. Do kláštera byly vyslány o dva roky později premonstrátky z Louňovic. Předpokládá se, že sestry přišly již do připravených prostor. Víme také, že počáteční hmotné zajištění kláštera nebylo nikterak veliké - šlo o tři vsi a patronáty nad šesti kostely. Po smrti posledního z Vilémových přímých potomků Oldřicha z Drnholce v bitvě u Laa (1273), o němž víme, že byl v klášteře pohřben, se roku 1284 ujal zakladatelských práv český král Václav II. V tomto období, které trvalo až do počátku 14. století, byla zřejmě ekonomická situace kláštera př́iznivá. Konvent zvětšoval své majetky, a patrně bylo přistoupeno i k určitým stavebním úpravám na konventních budovách. Již před polovinou 14. století však dochází k výprodeji některých statků, což bývá obvykle spojováno s intenzivnější stavební činností, která snad probíhala až do počátku 15 . století. Jedním z nepř́ímých dokladů těchto prací je výzva Bonifáce IX. z roku 1390 k podpoře obnovy kláštera, protože pro své stáří vyžaduje značných oprav. Tomu odpovídá i zpráva z roku 1388, ve které se dozvídáme, že klášter neměl kapitulní sín̆, protože volba probošta probíhala v refektáři, kde bylo zvykem konat kapitulní shromáždění.

Traduje se, že klášter byl vypálen roku 1423 za husitských vojenských operací na jižní Moravě. ${ }^{3}$ Po husitských válkách se hospodářská situace kláštera postupně stabilizovala a do počátku 16. století patřil dolnokounický probošt mezi nejvýznamnější církevní preláty na Moravě. V dalších desetiletích však nastal opětovný úpadek, který vedl v roce 1537 k prodeji kláštera Jiřímu

2 Historický exkurz je založen na doposud známých a publikovaných pramenech, které jsou velmi kusé. Jde o konvolut 99 listin, na základě kterých však takřka nelze postihnout stavební vývoj. Listiny dolnokounického kláštera se dostaly z majetku Drnovských z Drnovic do rukou Boskoviců, po smrti Jana Šembery je jako dědictví získal Karel z Lichtenštejna. V archivu Lichtenštejnů jsou doposud (viz Bistřický a kol. 1991, 8).

3 Tato událost však není nijak historicky doložena. 


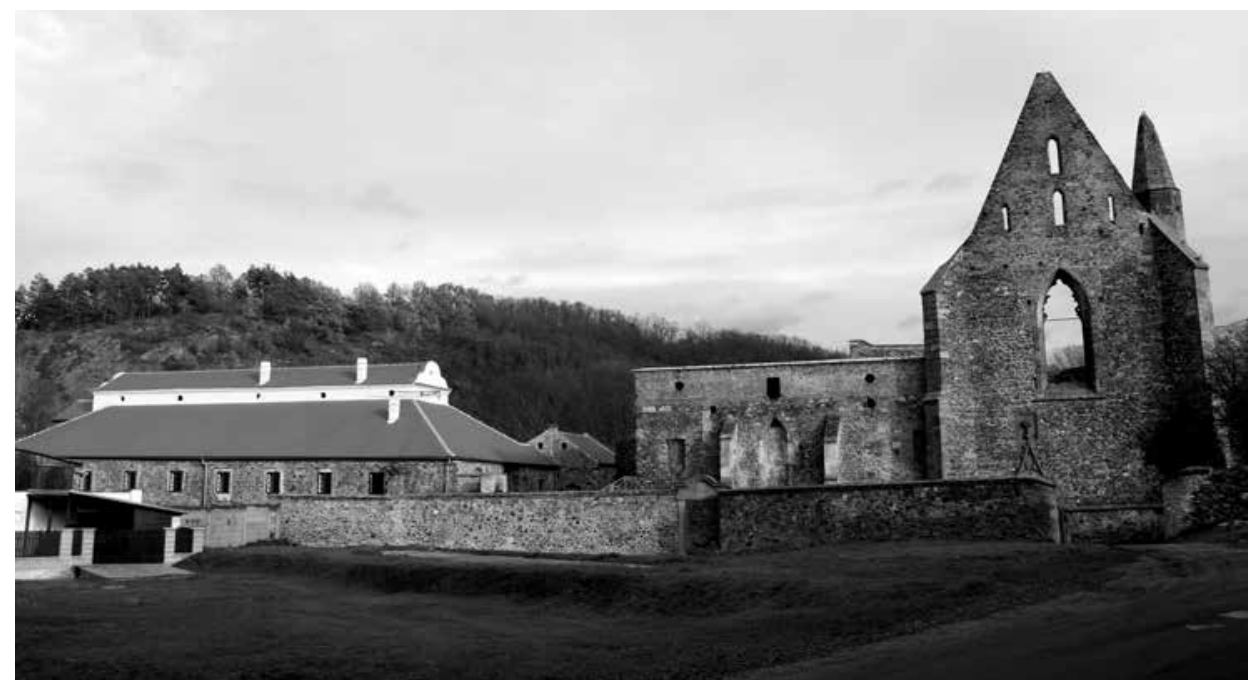

Obr. 2. Dolní Kounice, okr. Brno-venkov. Celkový pohled na klášter od západu. Vpravo je patrné průčelí kostela a vlevo budova barokního konventu. Archiv Archaia Brno, o.p.s.

Abb. 2. Dolní Kounice, Bez. Brno-Land. Gesamtansicht des Klosters von Westen. Rechts die Fassade der Kirche und links das Gebäude des Barockkonvents. Archiv Archaia Brno, o.p.s.

Žabkovi z Limberka. Ten zamýšlel v konventním kostele zř́́dit rodovou hrobku a stavebně zasáhl i do budov konventu, které neodpovídaly světskému poslání. Následně byly konventní budovy využívány převážně $\mathrm{k}$ hospodářským účelům. Roku 1699 postoupil celý areál tehdejší majitel panství Ferdinand z Dietrichsteina strahovské kanonii, která hodlala klášter obnovit. Brzy poté byla vysvěcena jedna $\mathrm{z}$ klášterních kaplí a současně s opravou stávajících budov probíhala výstavba barokního konventu. V roce 1703 byl vysvěcen opravený kostel, záhy však i s ostatními budovami podlehl rozsáhlému požáru. Po ukončení oprav byli od roku 1729 do kláštera dosazováni strahovští administrátoři, což trvalo až do roku 1808, kdy jej pražští premonstráti postoupili nazpět rodině Dietrichsteinů.

První novodobé zabezpečovací práce ruiny klášterního areálu proběhly v letech 1926 až 1933 (Borovský 2005, 27-28; Foltýn 2005, 277-285; Kuča 1996, 716; Líbal 2001, 78-81; Samek 1994, 391-393; Prokop 1904, 334-338).

\section{Archeologický a stavebně historický exkurz}

Stavební dějiny kláštera relativně podrobně popsal Augustin Prokop ve svém monumentálním díle již na počátku minulého století (Prokop 1904, 334-338). Cílem terénních průzkumů se klášter stal až v letech 1990 až 1993, kdy zde byly provedeny sondáže, které měly ověřit hypotézy týkající se stavebního vývoje konventu a kostela. Výzkum prováděl seminář umění FF UJEP (dnes Masarykova univerzita) ve formě „,podpovrchového stavebně historického průzkumu“, který se soustředil převážně na odhalená zdiva (Konečný-Borský-Hořínek 1994, 262-273). U průzkumů bohužel nebyla uplatněna řádná metodika archeologické exkavace a dokumentace, což dnes vede k řadě staronových otázek a určité revizi tehdejších zjištění. ${ }^{4}$ Cílem sondáží bylo doložit stavebně historická pozorování, respektive ověřit jejich závěry s ohledem na nejstarší podobu konventního kostela, za jehož relikt (presbytář) byla považována konventní kaple sv. Jana Křtitele. Ve východní části kaple byly odkryty základy konstrukce interpretované jako apsida konventního kostela. V souvislosti s dalším pozorováním byla celá situace vyhodnocena jako

4 Do budoucna bude pro případnou revizi nejschůdnějším řešením opětovné odkrytí sond položených v letech 1990 až 1993 a jejich řádná dokumentace. 
pozůstatek baziliky s tím, že substrukce zdiva trojlodí se dochovala ve zdivu kvadratury, která ji svou dispozicí respektuje. Takto formulované závěry doposud přebírá odborná literatura (např. Foltýn a kol. 2005, 282; Kuča 1996, 716). Nový stavebně historický průzkum zahrnující kostel a patrový ambit byl proveden v roce 2005 před prripravovanou obnovou areálu, nepřinesl však žádný významnější posun v poznání nejstaršího stavebního vývoje (Keberlová 2005). Drobné archeologické sondážní práce podnikl v letech 2002 a 2013 i Josef Unger. Ten při výzkumu v místech při západním vstupním portálu do kostela (2002) zjistil, že jeho základ narušuje starší pohřby, zatímco výzkum v prostoru rajského dvora (2013) doložil existenci starších zdí, než je ambit ze 14. století (Unger 2002; Kovář 2014). Zmínit je potřeba i geofyzikální průzkum, který se uskutečnil v celém prostoru sakrální stavby v roce 2011. Jeho cílem bylo upřesnit, ověřit a doplnit průběh různých architektonických prvků zjištěných výzkumem v minulosti a připravit tím i podklady pro navazující archeologické odkryvy (Hašek-Konečný 2014, 362).

Plošně prozatím nejrozsáhlejší archeologický výzkum doprovázel obnovu barokního konventu v letech 2012 a 2013. Záchranný výzkum byl realizován formou dohledu nad zemními pracemi, který byl rozšśřren o vhodně umístěné zjišt’ovací sondy (Peška 2013). ${ }^{5}$

\section{Stavební dějiny ${ }^{6}$}

Jak již bylo řečeno, z původního středověkého klášterního komplexu se dochovalo pouze torzo kostela s patrovým ambitem, sousedící na severu s barokním konventem.

Cílem výzkumů v letech 1990 až 1993 bylo ověření dispozice románské baziliky dokončené na počátku 13. století, jež se měla nacházet podle autorů právě v prostoru pozdějšího ambitu. Předpokládali, že jde o stavební analogii klášterního kostela premonstrátů v Louce u Znojma. ${ }^{7}$ Ke gotické novostavbě kostela a vlastního konventu se pak mělo přikročit až ve druhé čtvrtině 14. století, ${ }^{8}$ snad v návaznosti na výstavbu hradu. Stavební práce měly být dokončeny někdy na počátku 15. století. Autoři výzkumu tak usuzují z historických pramenů, které poukazují na velké zadlužení kláštera před polovinou 14. století. Po dobu výstavby nového kostela měla stará románská bazilika sloužit potřebám konventu. Tomuto předpokladu pak odpovídá i slohové pojednání dochovaného kostela. Jeho půdorysná dispozice ve tvaru latinského kříže byla ve stejné době použita také starobrněnskými cisterciačkami při stavbě kostela Nanebevzetí $\mathrm{P}$. Marie. Na místě románské baziliky byla vybudována patrová křížová chodba za částečného využití obvodových zdiv baziliky. V prostoru někdejšího presbytáře byla postavena kaple zasvěcená sv. Janu Křtiteli, kterou známe z pramenů k roku 1354. Kaple s vysokou gotickou klenbou o dvou polích byla později využívána jako kapitulní sín. Při průčelí byla do lodi nového kostela vložena empora pro sestry, která zabírala v celém rozsahu tři západní pole. Podlaha empory byla nejprve vynesena na konzoly a teprve později došlo k jejímu podklenutí na tři středové pilíře. Př́stup byl zajištěn z patra ambitu nebo $\mathrm{z}$ točitého schodiště v jihozápadním koutě lodi. Až v následné fázi,

\footnotetext{
5 Začištěna a zdokumentována byla v celém rozsahu jižní část chodby (1.01) s přilehlými místnostmi 1.04 až $1.07,1.22$ až 1.19 . V tomto prostoru byla také položena většina zjišstovacích sond (S1 až S2, S7, S8, S11 až S15), které byly situovány při odhalených starších základech pro ověření jejich dalšího průběhu a stáríi. V severní polovině konventu nebyly až na místnost 1.16 žádné relikty starších zděných konstrukcí nalezeny, což souvisí se skutečností, že geologické podloži v těchto místech klesá směrem k řece Jihlavě. Vzniklo zde tedy mocnější souvrství, jímž byl vyrovnán terén před výstavbou barokního konventu. Tato skutečnost byla dokumentována na řezech výkopů pro odvlhčení při východní (S16) a západní stěně konventu. V severní části dno výkopu pro odvlhčení nedosáhlo úrovně středověkého terénu.

6 Tato část vychází z dosavadní literatury ke klášteru, především z textu Kláry Benešovské obsaženého v encyklopedii moravských a slezských klášterů, což je poslední publikovaná stat' ke stavebním dějinám dolnokounického kláštera (Foltýn a kol. 2005, 277-285). Jako určitý protipól nebo lépe řečeno diskusní doplněk jsme využili prací Dobroslava Líbala a Bohumila Samka, které jsou citovány v několika následujících poznámkách (Líbal 2001, 78-91; Samek 1994, 391-393). Názor autorů př́spěvku na stavební vývoj kláštera je předložen v závěrečné diskusi.

7 D. Líbal usuzuje, že se starší kostel nacházel pod presbytářem kostela současného, o němž předpokládá, že byl zachován až do té doby, než se k němu přibližila novostavba budovaná od západního průčelí (Líbal 2001, 80), Bohumil Samek, stejně jako Karel Kuča bez udání důvodů uvažují o dřevěném provizoriu (Samek 1994, 391; Kuča 1996, 716; Foltýn a kol. 2005, 283).

8 D. Líbal vyslovil teorii, že při výstavbě kostela budovaného od západního průčelí, předtím než se dosáhlo transeptu, došlo k výrazně kvalitativn změně plánu. Jejím projevem mají být lineárně pojaté svazkové přípory předpokládající vyžlabená žebra. Zároveň pak byla vystavěna podklenutá tribuna a došlo k přenesení hlavního západního portálu. Při dalši stavební změně byly svazky př́ípor ukončeny baldachýny, na které byla nasazena hruškovitě profilovaná žebra. Výběhy hruškovitě profilovaných žeber naznačují, že hlavní lod'i transept byly zaklenuty. Presbytář v původní podobě byl již cele výsledkem změny plánu, po němž se prosadil architektonický zjev výrazně lineárního zaměření. Etapu lze datovat do třetí čtvrti 14. století. Ovšem převažují tu vlastně architektonické doklady z období snížení kostela, při kterém byl vyzdvižen i nový západní štít. Podnětem tu byl podle stop požár. Přes všechny nejasnosti se jeví být nejpravděpodobnější, že kostel byl dokončen a zaklenut. Po vyhoření za husitských válek byl patrně až někdy v druhé polovině 15 . století kostel nouzově opraven a snížen. Klenbu vystřídal trámový strop (Líbal 2001, 80-81).
} 


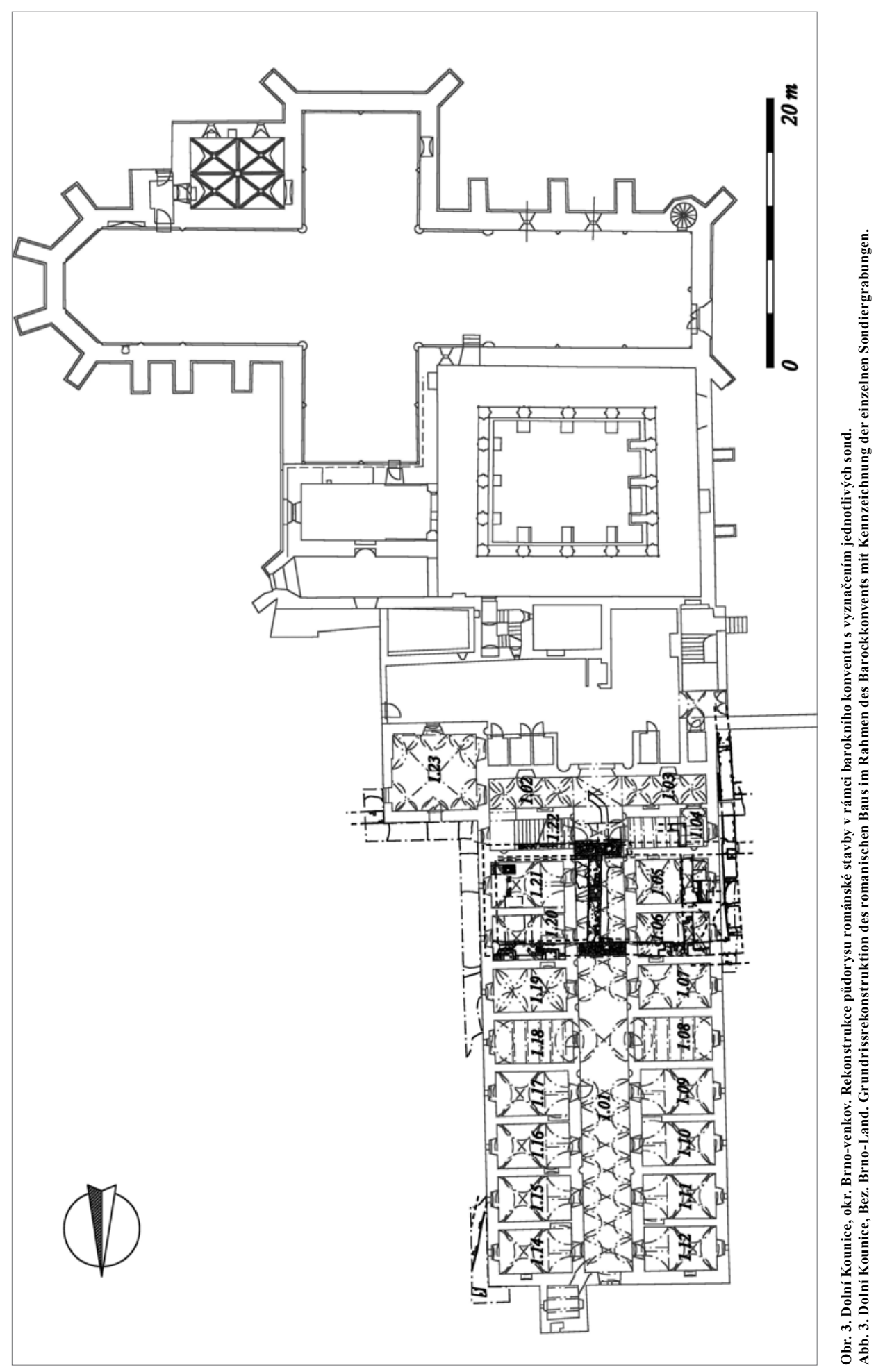




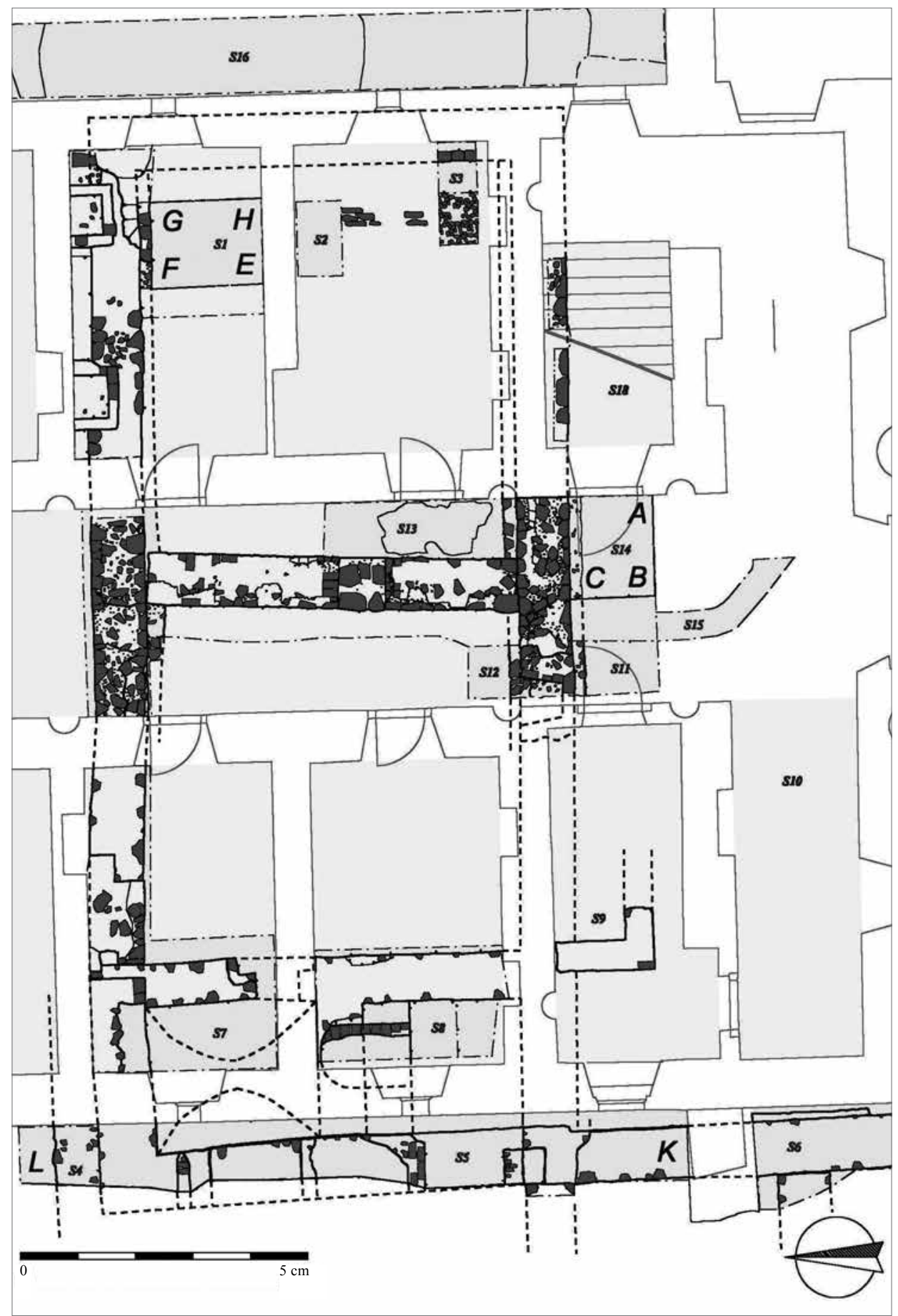

Obr. 4. Dolní Kounice, okr. Brno-venkov. Odkrytá románská a gotická zdiva v rámci barokního konventu, včetně umístění sond a řezủ. Archiv Archaia Brno, o.p.s.

Abb. 4. Dolní Kounice, Bez. Brno-Land. Freigelegtes romanisches und gotisches Mauerwerk im Barockkloster, einschließlich der Lage der Bohrlöcher und Schnitte. Archiv Archaia Brno, o.p.s. 
kterou realizovala jiná stavební hut', došlo k zaklenutí celého kostela a výstavbě patrového ambitu, který se klade do čtvrtého až pátého desetiletí 14. století. ${ }^{9}$ Horizontální spára v úrovni arkád a kleneb prŕizemí dokládá přerušení stavebních prací. V poničeném patře ambitu se z klenebního systému zachovaly pouze konzoly. Plánovaná dostavba konventu se patrně protáhla hluboko do druhé poloviny 14. století, kdy je k roku 1388 zmiňován refektár.

Při výstavbě kláštera se uplatnila architektonická sochařská plastika mající obdobu ve výzdobě vídeňského svatoštěpánského dómu z první třetiny 14 . století. Čtyřem polím klenby v lodi patří zřejmě čtyři figurální svorníky, které jsou dnes uloženy v Moravské galerii v Brně. Slohu svorníků a konzol se vymyká archaický ráz tympanonu západního vstupu do kostela. Opravu ambitu $\mathrm{v}$ době restaurace kláštera strahovskými premonstráty dokládá nápis na svorníku jihozápadního pole „RESTAURATUM A. MDCCI V A.S.“. V tomto období byl severně ambitu postaven i tzv. barokní konvent (Foltýn a kol. 2005, 282-284).

\section{Výsledky výzkumu z let 2012 až 2013}

Při výzkumu doprovázejícím výkopy pro odvlhčení zdiva při západní a východní venkovní stěně barokního konventu i v interiéru jeho jižní části ${ }^{10}$ byly při snižování úrovní podlah zachyceny pozůstatky zdiva několika stavebních fází zaniklých středověkých klášterních budov, jejichž existence nebyla známa.

Pro stratigrafický pořádek lokality je třeba uvést, že nejstarší zachycené osídlení, které zde bylo doložené, pochází z období pravěku. Vyvýšená část říční terasy byla již tehdy poměrně intenzivně osídlená, což dokládají na několika místech dokumentované kulturní vrstvy uložené na podloží. ${ }^{11}$

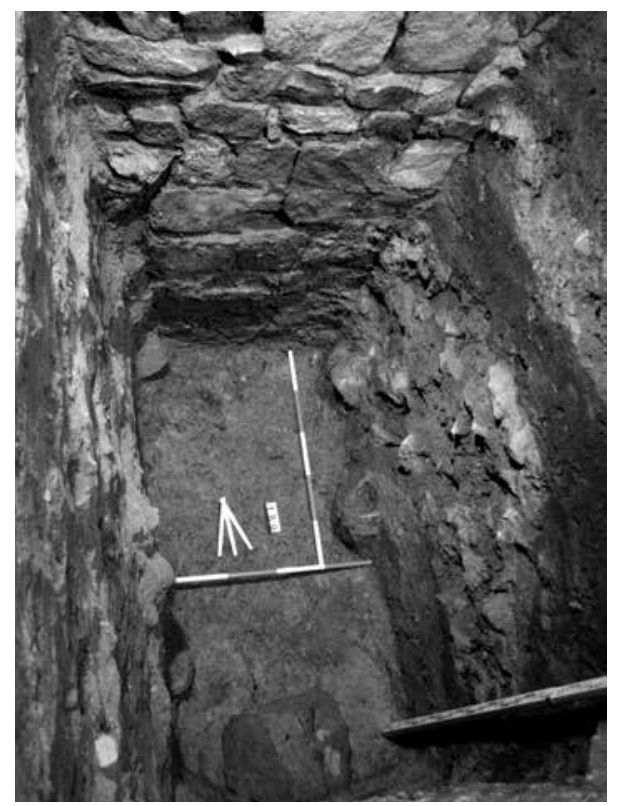

Obr. 5. Dolní Kounice, okr. Brno-venkov. Pohled od jihu do sondy S1. Archiv Archaia Brno, o.p.s.

Abb. 5. Dolní Kounice, Bez. Brno-Land. Blick von Süden in Sondierschnitt S1. Archiv Archaia Brno, o.p.s.

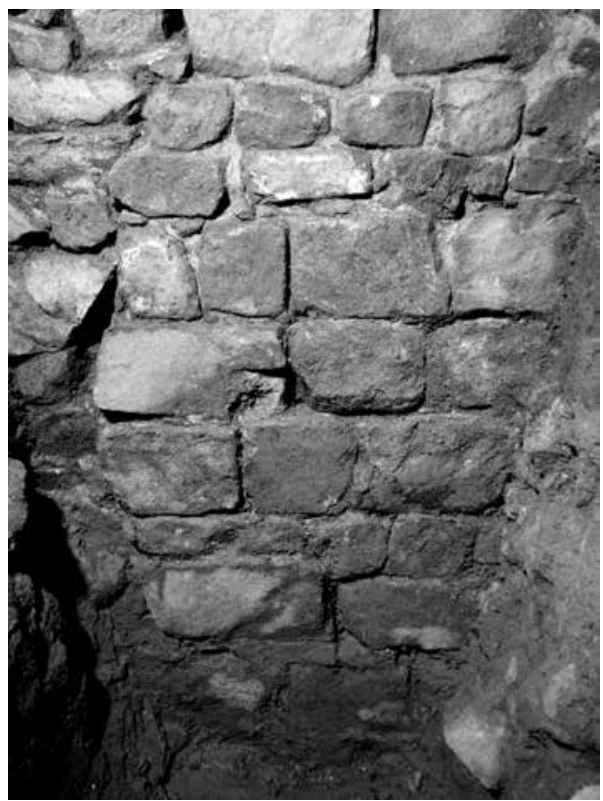

Obr. 6. Dolní Kounice, okr. Brno-venkov. Sonda 1 - severní stěna suterénu s kvádř́íkovým zdivem a gotickou „plombou“. Archiv Archaia Brno, o.p.s.

Abb. 6. Dolní Kounice, Bez. Brno-Land. Sondierschnitt 1, Nordwand des Souterrains mit Quadersteinmauerwerk und gotischer „Plombe“. Archiv Archaia Brno, o.p.s.

9 D. Líbal předpokládá, že stavební osnova kostela i kláštera byla založena jednotně, někdy ve druhé čtvrti 14. století (Líbal 2001, 80).

10 Místnosti 1.04 až $1.06 ; 1.20$ až 1.22 a jižní část chodby 1.01

11 Jde o osídlení z doby bronzové. Kulturní vrstvy jsou dokumentovány v sondách S6, S11 a S14. 
Po zániku pravěkého sídliště byla na dlouhou dobu kontinuita osídlení přerušena, jeho další etapa je spojena až s počátky kláštera v závěru 12. století, respektive s dobou jeho založení bezprostředně předcházející. Skromné keramické nálezy ze svrchních částí zkulturněného pravěkého podložíi ${ }^{12}$ zřejmě již souvisí s budováním nejstarší klášterní (?) stavby, jejíž základy byly odhaleny záchranným výzkumem (1. fáze - raný středověk). Výzkum byl koncipován tak, aby se postupně podařilo odkrýt půdorys celého nejstaršího objektu, jenž měl dispozici obdélného jednotraktu (obr. 4). ${ }^{13}$ Vnější nadzemní zdivo o síle $0,9 \mathrm{~m}$ bylo vystavěno z nepravidelně opracovaných kvádrů z granodioritu ukládaných do řádků a spojovaných jemnou šedou vápennou maltou, zatímco jádro zdiva bylo pouze vylito maltou s kameny. Pod úrovní terénu bylo zdivo po obou stranách rozšířeno o předzáklad.${ }^{14}$ Stavba byla v rozsahu celého půdorysu podsklepená, její plocha činila takřka $110 \mathrm{~m}^{2}(17,0 \times 6,4 \mathrm{~m})$. Dochovaná výška nadzemní části zdiva $\mathrm{v}$ žádné ze sond nepřesáhla více než $0,3 \mathrm{~m}$. Oproti tehdejšímu terénu byl suterén zahlouben ca $2,3 \mathrm{~m}$ do podloží. Na základě situace dokumentované v sondě S1 lze předpokládat, že suterén byl primárně alespoň zčásti sklenutý kamennou valenou klenbou (obr. 5, 6, 7). ${ }^{15}$ Původní vstup do suterénu se nepodařilo prozatím zachytit. Velmi zajímavou situací doprovázející nejstarší stavbu

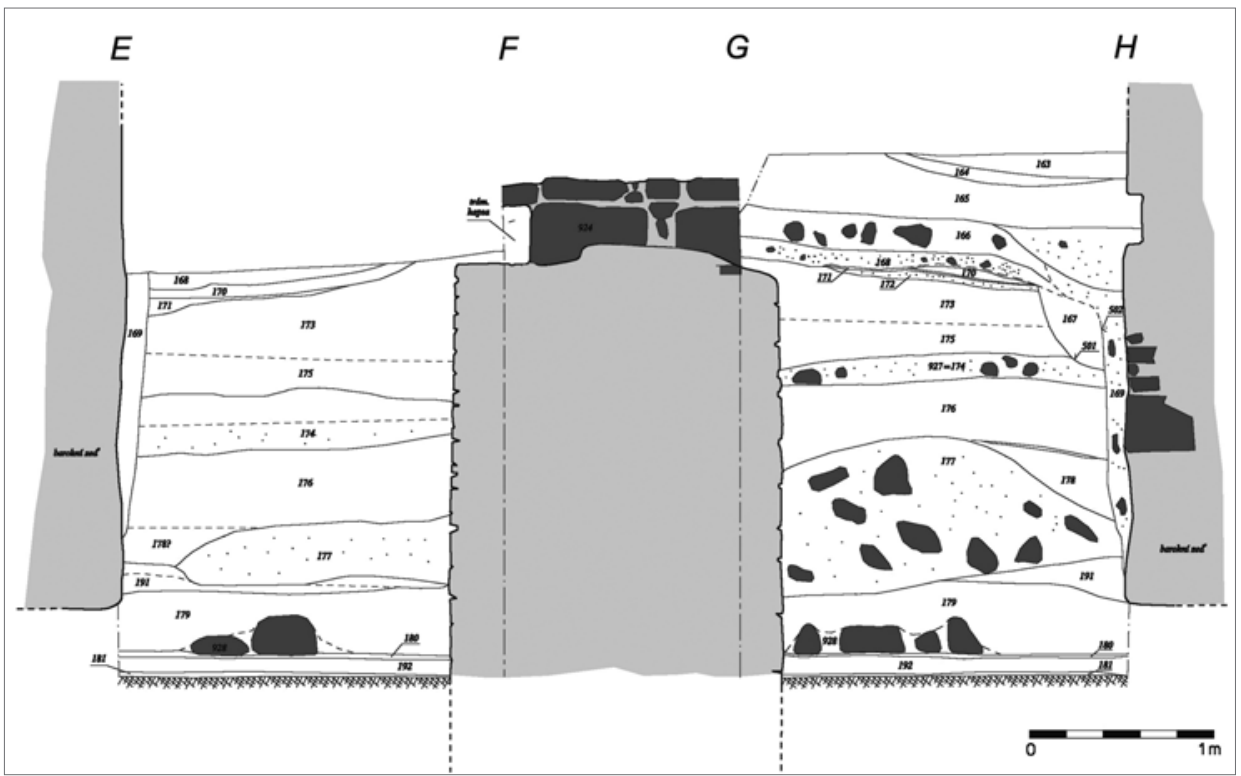

Obr. 7. Dolní Kounice, okr. Brno-venkov. Dokumentovaný řez v rámci sondy S1. Archiv Archaia Brno, o.p.s.

Abb. 7. Dolní Kounice, Bez. Brno-Land. Im Rahmen von Sondierschnitt S1 dokumentierter Schnitt. Archiv Archaia Brno, o.p.s.

je část asi 1,5m hlubokého výkopu zachyceného při vnější severní stěně románského objektu, který bychom mohli hypoteticky považovat za př́íkop obepínající stavbu. Výkop byl zasypán v průběhu 13. století v souvislosti se stavebními úpravami (obr. $8,9,10) .{ }^{16} \mathrm{~S}$ ohledem na charakter zdiva popisované stavby je třeba podotknout, že v celém areálu kláštera se dnes nenachází nadzemní ani základové zdivo podobné, natož shodné struktury. Tato skutečnost pak nahlodává v minulosti předloženou a dnes obecně přijímanou teorii o trojlodní bazilice obsažené ve hmotě

12 Sondy S11, S14 a S5 - s. j. 112, 218, 219, 229.

13 Úseky románského zdiva byly dokumentovány v sondách S1, S4, S5, S7, S11 až S14, S18 - s. j. 901, 910, 931, 924, $934,951$.

14 Šírka předzákladu (S1, S4, S11, S12, S13, S14) dosahovala zpravidla 0,2 až $0,3 \mathrm{~m}$, pouze v rámci sondy S4 byl dokumentován předzáklad o šířce $0,8 \mathrm{~m}$.

15 Indiciemi, jež nás vedly k domněnce o sklenutí, jsou: 1) rozšířený předzáklad; 2) zazděná mladší gotická plomba s. j. 933; 3) mohutná destrukce s. j. 177.

16 S4-s. j. 504. 


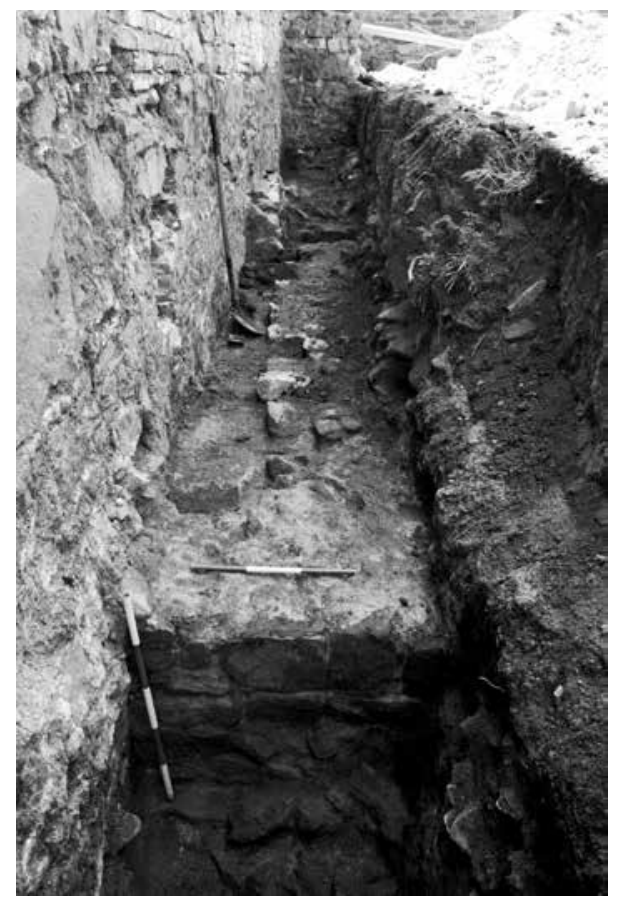

Obr. 8. Dolní Kounice, okr. Brno-venkov. Pohled od severu na úsek líce románské stavby dokumentované v rámci sondy $\mathrm{S} 4$. Archiv Archaia Brno, o.p.s.

Abb. 8. Dolní Kounice, Bez. Brno-Land. Blick von Norden auf einen Abschnitt der Flucht des im Rahmen von Sondierschnitt S4 dokumentierten romanischen Baus. Archiv Archaia Brno, o.p.s. kvadratury jakožto primárního kostela konventu (viz výše).

Další stavební etapa (2. fáze - vrcholný středověk) náleží vrcholnému středověku. V průběhu této stavební fáze byl románský objekt přestavěn, zároveň $\mathrm{v}$ areálu kláštera přibyla řada nových konventních budov. Pracovně můžeme toto období omezit na druhou třetinu 13. století. Pro tuto etapu je charakteristické používání hrubé žluté vápenné malty jako spojovacího materiálu a maloformátových cihel $(24 \times 12 \times 4,5 \mathrm{~cm})$ pro vyzdívku ostění vstupů a oken, případně pro vyzdění kleneb. Suterén románského konventu byl z větší části zasypán a podlaha přízemí byla ustálena na pochozí úrovni okolního terénu. V západní části objektu byly do někdejšího interiéru vloženy př́čky, které vymezily dva nově vzniklé sklípky se samostatnými venkovními vstupy prolomenými do západní stěny. Oba sklípky o přibližně stejné ploše $7 \mathrm{~m}^{2}$ byly zaklenuty klenbami z maloformátových cihel. Vstup do severnějšího z nich byl ještě v průběhu 13. století, nejpozději však ve století čtrnáctém zazděn, když byl z původního otvoru vyzděn úzký světlík. Nový př́stup do sklepa byl patrně řešen z interiéru. Další dokumentovanou stavební úpravu představuje krátký úsek gotického zdiva využívající v celé šîrce románského základu severní stěny, který můžeme interpretovat jako zazdívku původního románského, nebo mladšího gotického vstupu. Východní část stavby byla sklenuta kamennou klenbou, jejíž destrukci doložil výzkum v místnosti 1.21. Prozatím nejsme schopni rozhodnout, zda všechny úpravy spojené se zaklenutím byly současné. Celkovou přestavbu objektu v průběhu 13. století nejspíše vyvolala změna v požadavcích na využívání prostor, což snad ovlivnilo i zvýšení hladiny spodní vody. Současně s touto přestavbou probíhala v nejbližším okolí výstavba nových konventních budov, které do sebe nejstarší románskou stavbu organicky zapojily. Sondami S5 a S6 byly zachyceny základy nepodsklepené klášterní stavby přiléhající k jejímu jihozápadnímu nároží. Obdobně severovýchodně nejstaršího objektu byl v sondě S16 dokumentován krátký úsek gotického zdiva orientovaného ve směru jihojihozápad-severoseverovýchod neznámé, pravděpodobně hospodářské (?) stavby, jejiž interiér se dnes nachází v prostoru klášterní zahrady. Další objekty zřejmě navazovaly na románskou budovu i z východní strany, což dokládají mocné destrukce zachycené sondou S16. Lze tedy konstatovat, že 2. stavební fáze je nejvýraznější ze všech přestaveb dokumentovaných výzkumem.

Poslední etapu, která v zásadě uzavírá stavební vývoj středověkého konventu, představují přestavby a stavební úpravy provedené v pozdním středověku (3. fáze - pozdní středověk). Je obtížné přesněji stanovit mezníky pro období, ve kterém byly tyto stavební práce provedeny. Jako nejpravděpodobnější se nabízí doba stabilizace a obnovy kláštera po husitských válkách ukončená požárem středověkého konventu na přelomu 15. a 16. století. Požár doložený požárovým zásypem v sondě při jižní stěně románského objektu orientačně datuje drobný haléř krále Vladislava II. Jagelonského vyražený po roce 1482. Pro tuto stavební etapu je charakteristické použití šedobéžové tvrdé vápenné malty jako pojiva, smíšené zdivo sestávající z kamenů 


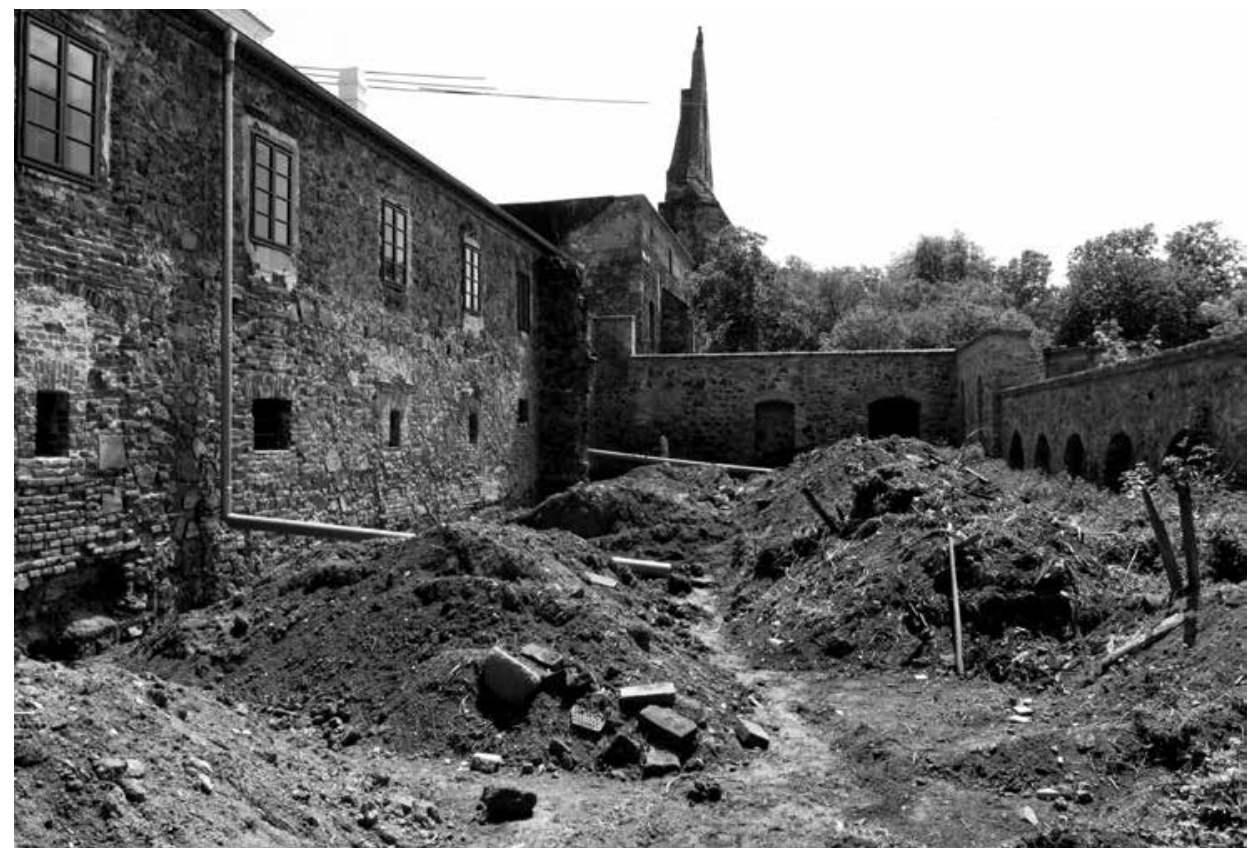

Obr. 9. Dolní Kounice, okr. Brno-venkov. Pohled od severozápadu na umístění sond S4 a S5 při budově barokního konventu. Archiv Archaia Brno, o.p.s.

Abb. 9. Dolní Kounice, Bez. Brno-Land. Blick von Nordwest auf die Lage der Sondierschnitte S4 und S5 am Gebäude des Barockkonvents. Archiv Archaia Brno, o.p.s.

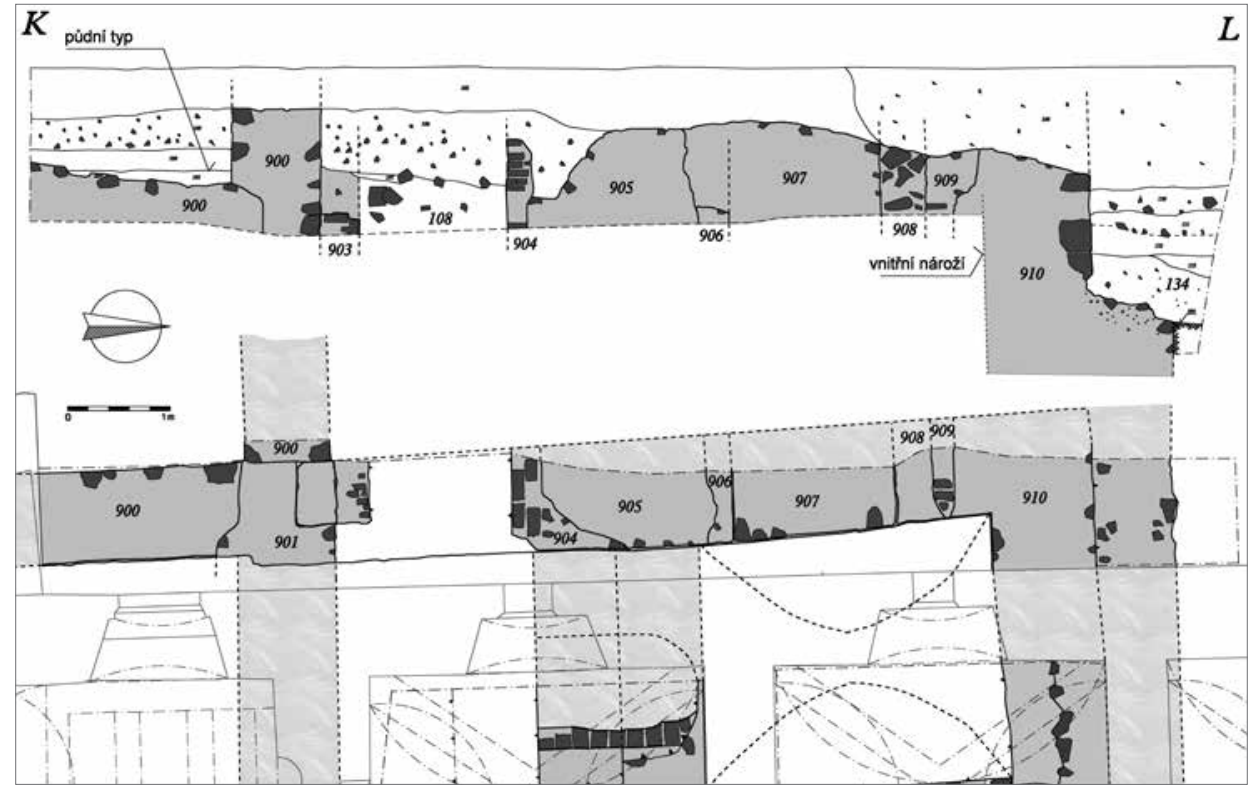

Obr. 10. Dolní Kounice, okr. Brno-venkov. Dokumentovaný řez v rámci sond S4 a S5. Archiv Archaia Brno, o.p.s.

Abb. 10. Dolní Kounice, Bez. Brno-Land. Im Rahmen der Sondierschnitte S4 und S5 dokumentierter Schnitt. Archiv Archaia Brno, o.p.s. 
a zlomků cihel i typická ostění vyzděná z vysokých gotických cihel. Stejně jako v předchozím období i nyní došlo k úpravám interiéru románského objektu. Prostor přízemí byl nově vloženou prř́čkou rozdělen na tři části, centrálně do ní byl proražen ca 0,8 m široký vstup. Do jižní, dosud románské stěny byla vložena nika, která zřejmě sloužila jako krbový otvor. Starší gotické klenby byly sneseny a prostor byl nově zastropen. Upraven byl také starší vstup z exteriéru v severní stěně. Definitivně byly v tomto období zasypány i dva malé sklípky při západním průčelí. Jižní sklípek byl upraven na pekárnu/kuchyni. Podlaha byla dosypáním zvýšena přibližně $0,5 \mathrm{~m}$ pod úroveň venkovního terénu a do gotické severozápadní př́čky bylo vloženo topeniště pece (ca $1,5 \times 1,0 \mathrm{~m}$ ), stojící částečně na nově přizděném soklu. Starší vstup z exteriéru byl znovu upraven a rozšířen na $1,3 \mathrm{~m}$. Severní sklípek sice nebyl sondován, ale na základě nově prolomeného vstupu z interiéru lze předpokládat, že i zde došlo ke zvýšení podlahy. V prostoru nad oběma sklípky můžeme hledat dymník tehdejší klášterní kuchyně. Při jižní stěně bylo dokumentováno subtilní nároží, které je patrně pozůstatkem schodiště do patra.

Pozdně gotické úpravy byly sledovány i v sousedních konventních stavbách. Do západního objektu byl nově vložen sklep a k hospodářské budově severovýchodně od konventu byl přiložen na západní straně přístavek. Jak již bylo řečeno výše, období pozdního středověku uzavírá požár nejstarší konventní budovy na přelomu 15. a 16. století. Kromě zmíněného haléře krále Vladislava II. Jagelonského byl z požárových planýrek získán rozsáhlý soubor zlomků kuchyňské keramiky a pozdně gotických reliéfních komorových kachlů.
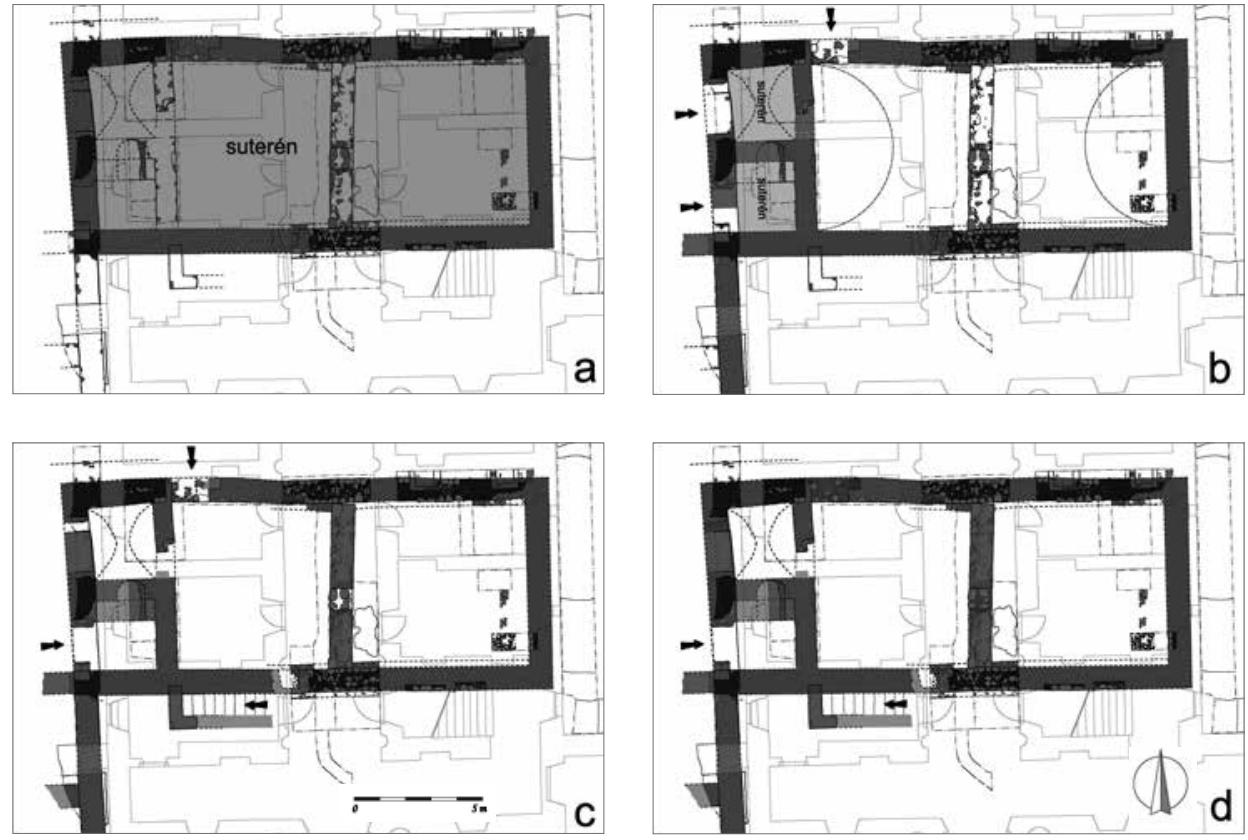

Obr. 11. Dolní Kounice, okr. Brno-venkov. Stavební fáze interpretované v rámci odkrytého románského objektu. a - stavební fáze 1- závěr 12. století; b - stavební fáze 2-13. století; c - stavební fáze 3-15. století; d-stavební fáze 4-16. století. Archiv Archaia Brno, o.p.s.

Abb. 11. Dolní Kounice, Bez. Brno-Land. Im Rahmen des freigelegten romanischen Objekts interpretierte Bauphasen. a - Bauphase 1 - Ende 12. Jhdt.; b-Bauphase 2 - 13. Jhdt.; c-Bauphase 3 - 15. Jhdt.; d - Bauphase 4 - 16. Jhdt. Archiv Archaia Brno, o. p.s.

Stavební úpravy na středověkém konventu byly provedeny i v následujícím období (4. fáze - renesance). Jde vesměs o úpravy nevýznamného charakteru, jakými jsou zazdívka světlíku v západní stěně románského objektu, př́ípadně zazdívka pozdně gotického vstupu v interiéru. V průběhu 16. a 17. století konvent chátral. Je otázkou, zda již v tomto období nebyl z jednotlivých staveb odvážen stavební materiál pro výstavbu a opravy domů v městečku. Z tohoto 


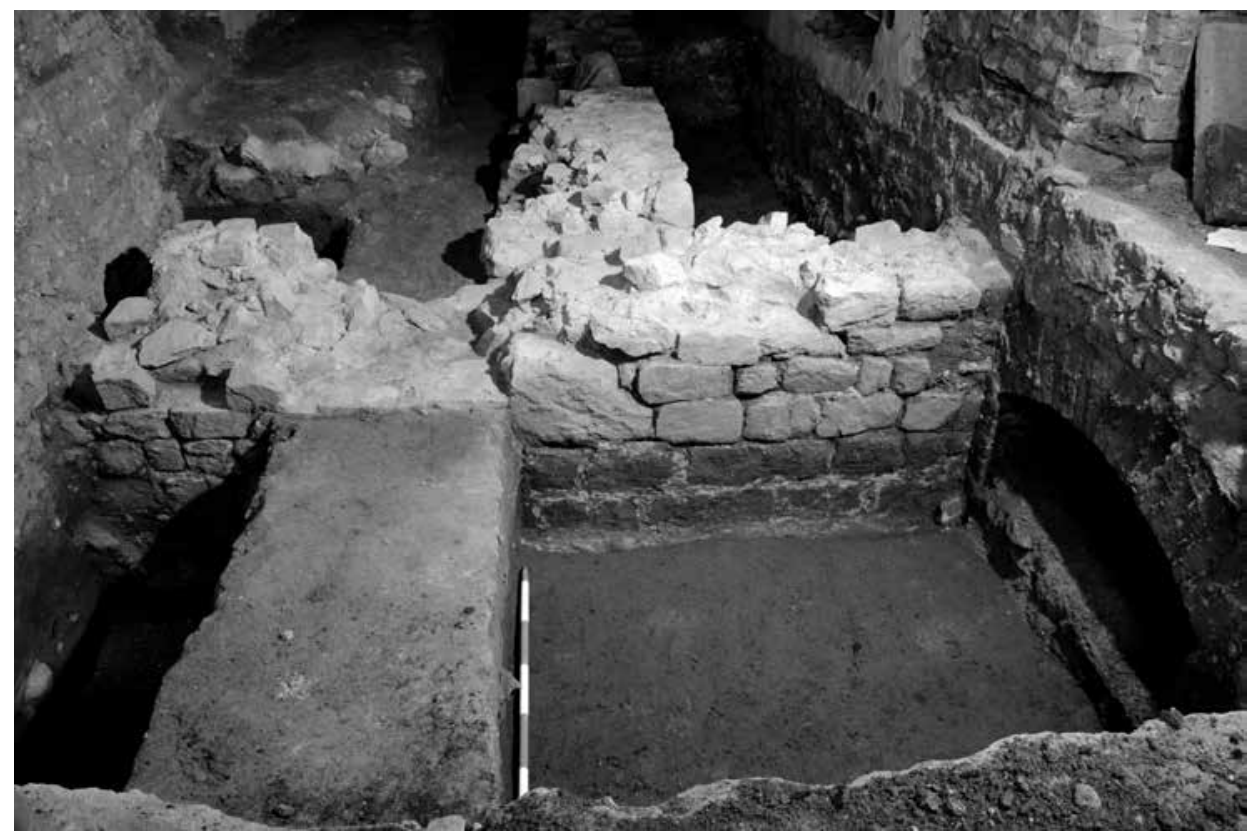

Obr. 12. Dolní Kounice, okr. Brno-venkov. Pohled od jihu na líc románského zdiva v sondách S11 a S14. Archiv Archaia Brno, o.p.s. Abb. 12. Dolní Kounice, Bez. Brno-Land. Blick von Süden auf die Flucht des romanischen Mauerwerks in den Sondierschnitten S11 und S14. Archiv Archaia Brno, o.p.s.

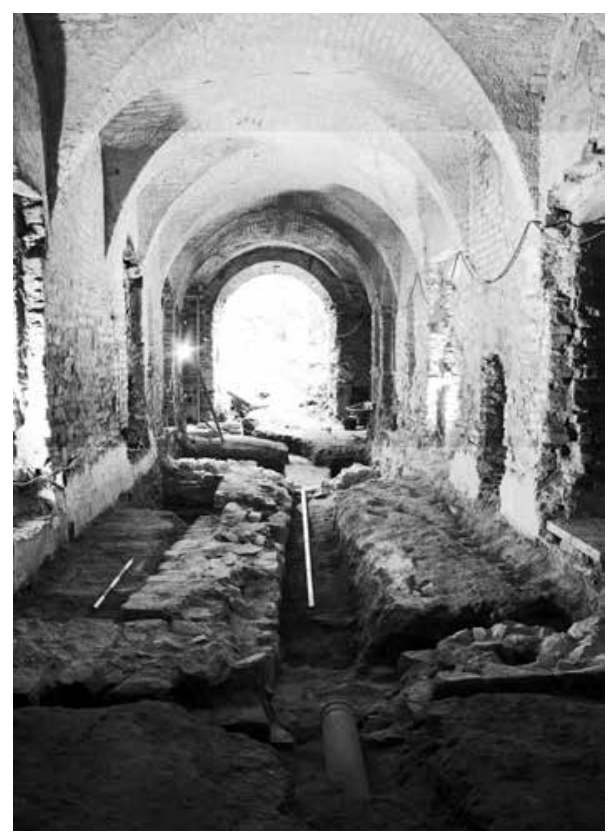

Obr. 13. Dolní Kounice, okr. Brno-venkov. Pohled od severu na substrukce stř̌edověkých zdiv $\mathbf{v}$ chodbě barokního konventu. Archiv Archaia Brno, o.p.s.

Abb. 13. Dolní Kounice, Bez. Brno-Land. Blick von Norden auf die Substruktion der mittelalterlichen Gemäuer im Gang des Barockkonvents. Archiv Archaia Brno, o.p.s. období snad pochází některé dokumentované rozměrné novověké jámy, jejichž interpretace není jasná. Po postoupení areálu kláštera tehdejším majitelem Ferdinandem z Dietrichsteina strahovské kanonii byla zahájena jeho postupná obnova. Sama stavba tzv. barokního konventu (5. fáze) byla dokončena $\mathrm{k}$ roku 1714 (Foltýn 2005, 281; Bartáková 2006, 30). Na skice města Dolních Kounic, jež je součástí tzv. sbírky F. F. Nicolaie z počátku 18. století, je zřetelně vidět půdorysné rozvržení klášterních staveb, které neodpovídá dnešnímu stavu (obr. 15). To znamená, že na ní ještě není zobrazen barokní konvent. Lze tedy usuzovat, že klášter je zde zachycen částečně ještě ve své středověké dispozici. Ani barokní novostavba nebyla jednorázovou záležitostí. Její stavební vývoj dokládají nejméně dvě stavební fáze. V místnosti 1.20 byla odhalena ústí dvou světlíků prolomených do severní stěny někdejší románské stavby vedoucích ze sousední místnosti 1.19 , což poukazuje na její podsklepení. Zasypaný sklep byl dokumentován i pod místností 1.22. Zde byl dokonce vybudován i vstup do nerealizovaného (plánovaného?) sklepa pod chodbou. Oba zasypané sklepy jsou ne- 
pochybně součástí barokního konventu. Otázkou však zůstává, zda byly sklepy někdy vůbec dostavěny, nebo došlo k jejich zasypání v souvislosti se změnou projektu ještě v průběhu stavby.

\section{Diskuse a poznámky ke stavebnímu vývoji stř̌edověkého konventu}

Prezentovaný archeologický záchranný výzkum přinesl nové, mnohdy zásadní poznatky, které nám umožňují korigovat pohled na středověké stavební dějiny kláštera.

Za nejvýznamnější poznatek považujeme odkrytí solitérně stojící, jednotraktové a v celém rozsahu podsklepené obdélné stavby o vnějších rozměrech 18,6×8,6 m. Objekt orientovaný

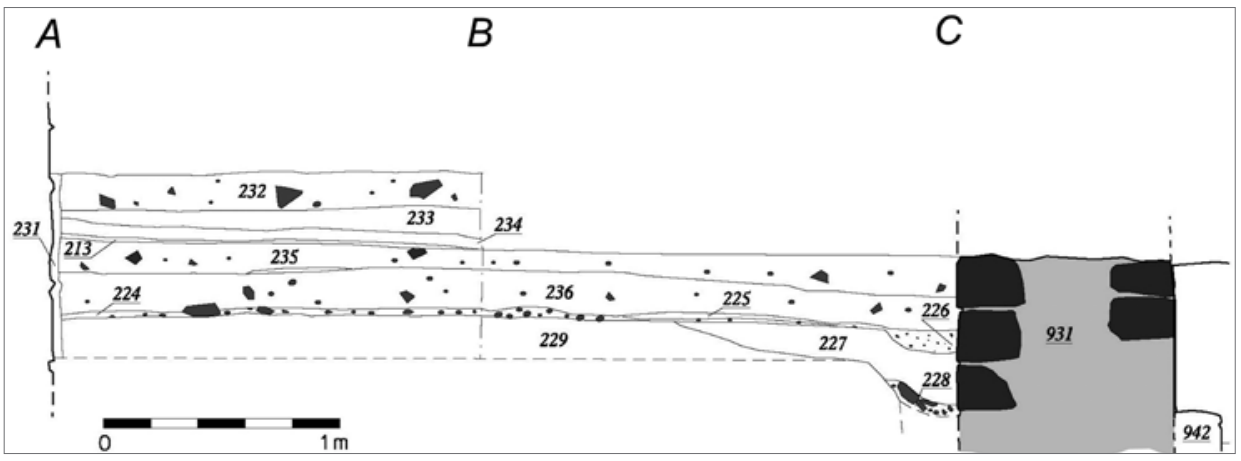

Obr. 14. Dolní Kounice, okr. Brno-venkov. Dokumentovaný řez v rámci sondy S14. Archiv Archaia Brno, o.p.s.

Abb. 14. Dolní Kounice, Bez. Brno-Land. Im Rahmen von Sondierschnitt S14 dokumentierter Schnitt. Archiv Archaia Brno, o.p.s.

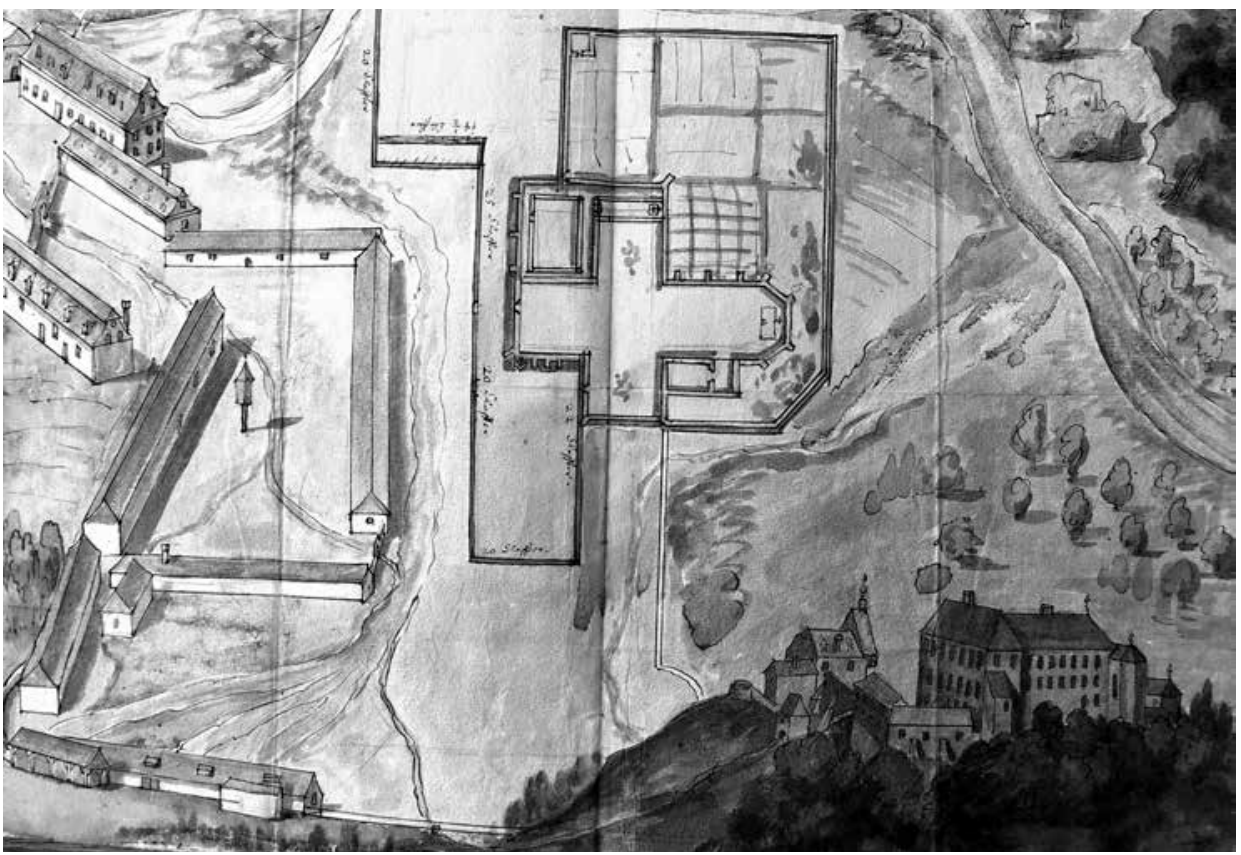

Obr. 15. Kolorovaná kresba, která byla př́lohou smlouvy o odstoupení kláštera premonstrátům z roku 1698; smlouva i kresba jsou uloženy v MZA v Brně. Nevyplněné linie zdiv jsou zřejmě stávající konstrukce, tmavě šedou výplní (na západě) je vyznačena nová zed', nově vymezující klášterní pozemek. Archiv Archaia Brno, o.p.s.

Abb. 15. Kolorierte Zeichnung, die Anhang des Abtretungsvertrags an die Prämonstratenser aus dem Jahr 1698 ist; Vertrag und Zeichnung werden im Mährischen Landesarchiv Brno aufbewahrt. Die weißen Linien stellen offenbar bestehende Mauern dar, dunkelgrau gekennzeichnet (im Westen) ist eine neue Mauer, die das Klostergelände neu abgrenzt. Archiv Archaia Brno, o.p.s. 
delší osou ve směru východ-západ byl postaven z kvádř́íkového zdiva a stratigraficky jej lze datovat do závěru 12. století. Na stavbu nenavazovaly žádné další objekty stejného stáří a jediným známým románským prvkem $\mathrm{v}$ areálu je torzo původního kostela, respektive relikt jeho apsidy, který byl odkryt v letech 1990-1992 (od severovýchodního nároží činí vzdálenost ca $25 \mathrm{~m}$ ). K odhalené jednotraktové budově byly v průběhu 13. století z východní i západní strany přistavěny další konventní stavby, jejichž detailní prostorová dispozice je prozatím neznámá. Pokud budeme uvažovat o její interpretaci, vyvstávají nám přinejmenším dvě základní hypotézy vztahující se k její funkci.

Jako prvotní interpretace se nabízí možnost, že před sebou máme nejstarší stavbu konventu. Vzhledem k umístění objektu vůči předpokládanému kostelu by mělo jít podle tradičního benediktinského schématu o refektář (srov. např. Vlček-Sommer-Foltýn 1998, 29-39; BindingUntermann 2001, 49-74). Mohlo by také jít i o víceúčelovou stavbu, která sdružovala v první fázi existence konventu funkce dormitáře, refektáře a kapitulní síně. Mathias Untermann tyto stavby nazývá „mnišskými domy“, které někdy mohou být označeny také latinským termínem pars pro toto a mají kořeny v raném středověku (Untermann 1996, 233). Na rozdíl od dolnokounického objektu však ve 12. století zpravidla jde o vícedílné stavby situované ve východním kř́́dle kláštera a napojené na kostel. Dispozice těchto budov se stala většinou východiskem k výstavbě dalších dvou křídel klauzury uzavírajících prostor kolem rajského dvora. Na jihozápadní nároží odkryté stavby sice navazovala gotická konventní budova, která vymezila vnitřní část nově vzniklého dvora, a již bychom mohli případně považovat za západní křídlo kvadratury, ale východní trakt, který byl pro život sester podstatnější, nebyl žádným výzkumem zachycen. Sondami byla také s největší pravděpodobností vyloučena existence „nejstaršího“ ambitu, o němž se předpokládalo, že byl vybudován při severní stěně baziliky. ${ }^{17}$ Ještě je zde možnost interpretovat stavbu jako staré proboštství, obdobně jako v prŕípadě románské palácové stavby v benediktinském opatství v Třebíči (Kolařík-Merta-Peška 2011), pro toto využití by však byl objekt krajně nevhodně situován uprostřed budoucích ženských konventních budov. Komunikace mužské a ženské části konventu byla $v$ rámci klauzury po celý středověk př́ísně oddělena.

V souvislosti s hledáním odpovědi na původní funkci odhalené stavby se vrátíme k hypotéze o románské klášterní bazilice (k této interpretaci viz výše). Struktura odkrytého kvádř́ikového zdiva románského jednotraktu, spojovaného jemnou šedou vápennou maltou, neodpovídá technice, kterou je vyzděna severní stěna ambitu považovaná za pozůstatek zdiva severní lodi někdejší baziliky. Ve zdivu severní stěny ambitu jsou kvádříky spojovány hrubou nažloutlou maltou, která je rozetřena, a rytým spárováním je do ní vyznačeno kvádrování. Obdobné malty známe z Brna počínaje druhou třetinou 13. století. Z černobílých fotografií z výzkumu z let 1990 až 1992 lze vyvodit, že ze všech fotograficky zachycených stavebních konstrukcí odpovídá svou formou románskému jednotraktu nejspíše torzo odkrytého presbytáře (pod kaplí). Zdivo identické nebo obdobné struktury nebylo zachyceno ani sondou před vstupem do kaple při východní stěně ambitu, která zde byla položena v roce 2013 (mimo jiné i za účelem ověření prrípadných základů lodi románské baziliky). Z popsaných skutečností je dle našeho názoru zřejmé, že forma stavby odkryté pod barokním konventem a struktura jejího zdiva je v rámci dolnokounického areálu prozatím jedinečná. Relikt apsidy, který jako jediný vykazuje obdobnou strukturu zdiva, bychom mohli hypoteticky považovat za apsidu menšího jednolodního kostela, který lze interpretovat jako vlastnickou svatyni Viléma z Pulína. Tím se dostáváme ke druhé hypotéze, která předpokládá, že stavba byla postavena již v předklášterním období, s konventem neměla primárně nic společného a byla do něj začleněna až následně. Jednou z indicií poukazujících na původně profánní charakter objektu je to, že stojí solitérně, nenavazují na něj další zděné nebo nezděné stavby a že je v celém rozsahu podsklepen. To se neslučuje se středověkou podobou refektáře ani víceúčelových mnišských domů (viz výše). Pro detailnější prostorovou srovnávací analýzu k počátku konventu nemáme prozatím dostatek vhodných analogii. Na Moravě jde o jednu z nejstarších budov, které jsou rozpoznány v raně středověkých klášterních areálech. V tomto ohledu

17 Ambit nebyl realizován ani v nedalekém klášteře cisterciaček v Oslavanech (Foltýn a kol. 2005, 592-593 ). 
nám nepomohou ani novější výzkumy českých premonstrátských klášterů v Teplé a Milevsku (Široký-Nováček 2011; Břicháček 2006). Na základě uvedených argumentů bychom se přiklonili spíše k interpretaci románského objektu jako primárně světské stavby, která byla konventu darována při jeho založení. Vzhledem k jednoduchému půdorysu a zřejmě i obehnání areálu př́kopem (viz sonda S4) můžeme s jistou opatrností stavbu považovat za sídlo zakladatele kláštera Viléma z Pulína. ${ }^{18}$ Ten premonstrátkám mohl předat i malý vlastnický kostel, ze kterého byl odkryt presbytář, stojící jižně jeho sídla (viz výše románská bazilika). Měli bychom tak před sebou sídlo představující dvorec, jaký známe z českého prostředí např́íklad v Týnci nad Sázavou 2. stavební etapa (souhrnně např. Varhaník 2007), v Bedřichově Světci (Klápště 1994, 31-38; 2005, 113-118), ve Chvojenu (Hejna 1983, 368n) nebo ve Vroutku (Hejna 1977, 69-70). Z bližšího okolí pak můžeme uvažovat především o zábrdovickém dvorci Lva z Klobouk; majitel jej daroval o něco později (1209) spolu se svým kostelem sv. Kunhuty také premonstrátům (Borovský 2005, 32-33; Černoušková-Borský 1999; 2002; Foltýn a kol. 2005, 233-239; Merta 2013, 108n). Dnes známe jen kapli sv. Kunhuty, o dvorci nevíme nic. Zde považujeme za důležité zmínit, že na falzu k založení dolnokounického kláštera je mezi svědky uveden také Lev z Klobouk (Bistřický a kol. 1991, 23). Dolnokounickou stavbu lze přiřadit do okruhu raných šlechtických hradů, pro něž je v německy mluvících zemích používán termín „Feste Haus“, jehož atributy naše stavba splňuje (např. Barz 1993; 2006).

Ze závěru 12. a počátku 13. století nemáme kromě torza v př́izemí patrového ambitu dochovány žádné konventní stavby. Že tato stavební fáze využila staršího (vlastnického) kostela, dokládá fotografie z výzkumu v letech 1991-1993. Je na ní patrný pozůstatek ústupkového vítězného oblouku, ke kterému je na spáru přiložena zed’ vyzděná z kvádrů s rozetřenou maltou, do níž je vyznačeno iluzivní spárování. Zda před sebou máme pozůstatky baziliky, je otázkou.

Někdy kolem poloviny 13. století se začalo s velkorysou výstavbou kláštera, což dokládá jeho západní křídlo, do kterého byla zakomponována i původní „palácová“ stavba. Pokud budeme uvažovat o tom, že dispozice kláštera se od tohoto období v zásadě nezměnila, tedy že jak ambit, tak kostel jsou od této doby na stejném místě, dosahovalo by křídlo délky takřka $26 \mathrm{~m}$. Pro charakter zděných konstrukcí tohoto období je charakteristická „oranžová“ malta a použití maloformátových cihel na vyzdění architektonických detailů, jako jsou vstupy či okna. Jejich pozůstatky jsou pak, mimo archeologicky zkoumané situace, patrné především v západní, venkovní zdi ambitu. Tento formát cihel byl také použit na vyzdění klenby nad místností v západním kř́íle konventu. ${ }^{19}$

Následný stavební horizont představuje výstavba ambitu a kaple (její umístění nad původním kostelem lze považovat za udržení tradice místa oltáře) v dnešní dispozici a založení novostavby konventního kostela. Ve zkoumaném prostoru se projevuje zaklenutím východní části nejstaršího jádra. Jmenované aktivity můžeme položit do druhé třetiny 14 . století. Z dnes neznámých důvodů nebyl ambit $\mathrm{v}$ této době dokončen, jeho zdi byly vyzdvihnuty do výše necelých $3 \mathrm{~m}$ a stavba byla přerušena. Podobně tomu bylo i u kostela. Další budovy konventu pro dané období neznáme. Ještě v průběhu 14. století došlo $\mathrm{k}$ dostavbě patrového ambitu a zřejmě i kostela (k dataci stavebního vývoje a postupu stavebních prací jiných badatelů viz výše).

Předpokládané poničení kláštera za husitských válek pak může dokládat rozsáhlá oprava kostela, pro kterou je typické masivní použití cihel vysokého formátu, z nichž jsou vyzděny části pobořených (?) zdí a také dozděna okna a západní štít. Drobné úpravy byly dokumentovány i v prostoru námi zkoumané archeologizované části konventu. Předpokládané další stavby kláštera z tohoto období se nedochovaly.

Areál kláštera byl upravován a přestavován v době, kdy se stal majetkem Žabky z Limberka. Stopy po těchto aktivitách nebyly zatím zachyceny archeologicky, nejlépe jsou patrné pouze $\mathrm{v}$ dochovaných stavbách, které se později staly součástí tzv. barokního konventu, přesněji v jeho

18 Sídlo Viléma z Pulína není dosud spolehlivě lokalizováno. Naposledy shrnuli dosavadní bádání nad umístěním Pulína např. Jan Studeník (diplomová práce 2010, 60-68) nebo L. Konečný (2011).

19 V Brně předpokládáme používání tohoto formátu cihel pro druhou polovinu 13. století s dozníváním na počátku století následujícího (HolubKolařík-Merta-Peška 2010). 
jihovýchodní části, která je v jádru renesanční. Pravděpodobně došlo i k úpravám konventního kostela, který byl zamýšlen jako rodová hrobka. Zda tyto práce byly dokončeny, nelze dnes doložit.

Doposud nikoliv zcela objasněnou kapitolu představuje snaha strahovských premonstrátů o renesanci kláštera na přelomu 17. a 18. století. V publikacích, v nichž se o klášteře píše (Foltýn a kol. 2005; Kuča 1996; Samek 1994), se dané období přechází konstatováním, že se tento pokus neúspěšně uskutečnil. Viktor Kotrba ve své knize Česká barokní gotika poukazuje na opomíjený rozměr celé akce: „Nápis na svorniku v jihozápadním klenebním poli ambitu Restauratum A. MDCCI V.A.S. (Restaurováno roku 1701, Vit opat strahovský) udává datum ukončeni této restaurátorské akce a prvni historizujici rekonstrukce středověké architektury v českých zemích. Tento počin nevyniká sice rozsahem a výtvarným efektem, ale zasluhuje plnou pozornost jako závažný projev sil, z kterých se rodila monumentální architektura české barokní gotiky obnovou a přestavbou klášterních chrámů v Sedlci, Kladrubech i Želivi“ (Kotrba 1979, 72-73). Je zajímavé, že tento Kotrbův postřeh, vztahující se k fenoménu české barokní gotiky, nezohlednila následně žádná práce věnovaná stavebním dějinám kláštera (naposledy např. Klára Benešovská v Encyklopedii moravských a slezských klášterů hovoří pouze o pietní opravě ambitu strahovskými premonstráty, viz Foltýn a kol. 2005, 283). Ze stavebních dějin kláštera víme, že strahovští opravili a roku 1703 i vysvětili klášterní kostel. V témž roce však došlo k požáru, který poničil nejen kostel, ale i nově vystavěné klášterní budovy. Víme tedy, že kostel byl opraven. Jeho přestavba mohla trvat až pět let, což je dost dlouhá doba na to, aby nešlo o opravu pouze provizorní. Teoreticky bychom tak mohli uvažovat o tom, že kostel byl, podobně jako ambit upraven v duchu barokní gotiky, včetně zaklenutí, což by bylo vcelku logické. Po více než dvousetletém chátrání bylo od roku 1926 to, co z něj zbylo (obvodové zdi), nikoliv zrovna citlivě (myšleno ve vztahu k zachování výpovědní hodnoty/autenticity stavby) v rámci zabezpečovacích prací opravováno (zděno cihlou a potřeno betonovou maltou), bohužel vše bez patřičné dokumentace. Je tedy velmi složité, ne-li zcela nemožné dnes goticko-barokní přestavbu doložit/zjistit. Snad jen $\mathrm{v}$ archivních pramenech. Po požáru v roce 1703 byl opraven pouze tzv. barokní konvent, ve kterém od roku 1729 působili strahovští administrátoři. Opravy doložil jak archeologický výzkum, tak i stavební dokumentace této budovy. Tento stav trval do roku 1808, kdy byl klášter prodán Janu Křtiteli z Dietrichštejna (Foltýn a kol. 2005, 281; Samek 1994, 392).

Výzkum realizovaný v letech 2011 až 2013 tak přispěl nejen k nejstarším stavebním dějinám konventu, jejichž poznání je dnes možné pouze za pomoci archeologie, ale v kombinaci $\mathrm{s}$ opětovným studiem stojících částí konventu také poukázal na možnost jejich odlišné interpretace. Zásadní otázku pak představuje prŕípadná existence sídla zakladatele kláštera Viléma z Pulína a jeho vlastnického kostela. Některé otázky tak byly alespoň částečně zodpovězeny, jiné se před námi naopak nově otevírají.

\section{Prameny a literatura}

BARTÁKOVÁ, A., 2006: Stavební vývoj kláštera Rosa Coeli v Dolních Kounicích na pozadí historických událostí, nepubl. bakalářská diplomová práce, Ústav hudební vědy, sdružená uměnovědná studia FF MU.

BARZ, D., 1993: Das „Feste Haus“ - ein früher Bautyp der Adelsburg, Burgen und Schlösser 93/I, 10-24.

- 2006: Zur baulichen Entwicklung der „Adelsburg“ im 10. und 11. Jahrhundert in Mittel- und Westeuropa. Forschungen zu Burgen und Schlössern. Band 9. Neue Forschungen zum frühen Burgenbau, 67-84. München - Berlin.

BINDING, G.-UNTERMANN, M., 2001: Kleine Kunstgeschichte der mittelalterlichen Ordensbaukunst in Deutschland. Darmstadt.

BISTŘICKÝ, J. a kol., 1991: Bystřrický, J.-Spurný, F.-Václavek, L.-Zemek, M., Moravské a slezské listiny liechtenštejnského archivu ve Vaduzu 1173-1380. Brno.

BOROVSKÝ, T., 2005: Kláštery, panovník a zakladatelé na středověké Moravě. Brno. 
BŘICHÁČEK, P., 2009: Archeologický výzkum jádra premonstrátského kláštera v Milevsku (okr. Písek). In: Vladislav II. Druhý král z Přemyslova rodu, k 850. výročí jeho korunovace (Mašek, M., ed.), 91-106. Praha.

ČERNOUŠKOVÁ, D.-BORSKÝ, P., 1999: Kostel sv. Kunhuty v Brně-Zábrdovicích. Stavebněhistorický průzkum. Brno.

- 2002: Kostel sv. Kunhuty v Brně-Zábrdovicích. Stavebněhistorický průzkum - dodatek. Brno.

DVOŘÁK, J., 2001: Stavební materiál kláštera Rosa Coeli v Dolních Kounicích, JM 30, $274-275$.

FOLTÝN, D. a kol., 2005: Encyklopedie moravských a slezských klášterů. Praha.

HAŠEK, V.-KONEČNÝ, L., 2014: Dosavadní průzkumy kláštera Rosa coeli v Dolních Kounicích, JM 50, 362-371.

HEJNA, A., 1977: Opevněná venkovská sídla doby Přemyslovské v Čechách - Befestigte Landsitze Přemyslidenzeit in Böhmen, AH 2, 69-79.

- 1983: Př́íspěvek ke studiu malých opevněných sídel doby Přemyslovské v Čechách, PA LXXIV, $366-435$.

HOLUB, P.-KOLAŘÍK, V.-MERTA, D.-PEŠKA, M., 2010: Středověká brněnská architektura z cihel Mittelalterliche Ziegelbauten in Brünn. In: Dějiny staveb. Sborník příspěvků z konference Dějiny staveb 2010, 139-159. Plzeň.

KEBRLOVÁ, E., 2005: Zřícenina kláštera s kostelem Rosa coeli, Dolní Kounice. Stavebněhistorický průzkum, ulož. v archivu Stavebního odboru Biskupství brněnského, Petrov 269/8, Brno.

KLÁPŠTĚ, J., 1994: Pamět' krajiny středověkého Mostecka. Most.

- 2005: Proměna českých zemí ve středověku. Praha.

KOLAŘÍK, V.-MERTA, D.-PEŠKA, M., 2011: Ke stavební dispozici areálu bývalého benediktinského opatství v Třebíči - Zur Baudisposition des Areals der ehemaligen Benediktinerabtei in Třebíč, AH 36, $153-163$.

KONEČNÝ, L., 2011: Počátky Drnholce v kontextu regionálních dějin. In: Drnholec, 73-92. Drnholec.

KONEČNÝ, L.-BORSKÝ, P.-HOŘÍNEK, J., 1994: K nejstarším stavebním dějinám kláštera Rosa coeli v Dolních Kounicích, JM 30, 264-273.

KOTRBA, V., 1979: Česká barokní gotika. Praha.

KOVÁŘ, J., 2014: Archeologicko-antropologický výzkum v areálu kláštera Rosa coeli v Dolních Kounicích, JM 50, 371-378.

KUČA, K., 1996: Města a městečka v Čechách, na Moravě a ve Slezsku. 1. díl A-G, Praha.

LÍBAL, D., 2001: Katalog gotické architektury v České republice do husitských válek. Praha.

MERTA, D., 2013: Bývalý premonstrátský klášter v Brně-Zábrdovicích (poznámky ke středověkým stavebním dějinám). In: Forum Urbes Medii Aevi VII/1-2. Kláštery ve středověkých městech střední Evropy, 108-117. Brno.

PEŠKA, M., 2013: Nálezová zpráva ze záchranného archeologického výzkumu, Dolní Kounice, klášter Rosa Coeli - barokní konvent, NZ čj. 65/2012, ulož. v archivu Archaia Brno, o.p.s.

PLAČEK, M., 2001: Ilustrovaná encyklopedie moravských hradů, hrádků a tvrzí. Praha.

PROKOP, A., 1904: Markgrafschaft Mähren in kunstgeschichtlicher Beziehung. Wien.

SAMEK, B., 1994: Umělecké památky Moravy a Slezska. Díl 1. A-I. Praha.

SEDLÁK, J., 2000: Architektura na Moravě a ve Slezsku za vlády lucemburských markrabat - Architektur in Mähren und Schlesien unter der Herrschaft der Luxemburger Markgrafen. In: Moravští Lucemburkové, 167-188. Brno.

STUDENÍK, J., 2010: Klášter Rosa Coeli - nejstarší šlechtická fundace na Moravě, diplomová práce, Ústav dějin křest’anského umění KTF UK.

ŠIROKÝ, R.-NOVÁČEK, K., 2011: První etapa výzkumu v areálu premonstrátské kanonie v Teplé, Památky západních Čech I, 37-47.

UNGER, J., 2002: Dolní Kounice 2002. Klášter Rosa coeli - odvodnění, NZ č. j. 195/02, ulož. v archivu Ústavu archeologické památkové péče v Brně.

UNTERMANN, M., 1996: Das „Mönschshaus“ in der früh- und hochmittelalterlichen Klosteranlage. Beobachtungen zu Lage und Raumaufteilung des Klausur-Ostflügels. In: Wohn- und Wirtschaftsbauten frühmittelalterlichen Klöster (Sennhauser, H. R., ed.), 233-258. Zürich.

VARHANÍK, J., 2007: K interpretaci výsledků archeologického výzkumu v Týnci nad Sázavou (o. Benešov). In: Archeologica Pragensia 2006, 228-243. Praha.

VLČEK, P.-SOMMER, P.-FOLTÝN, D., 1998: Encyklopedie českých klášterů. Praha. 


\section{Zusammenfassung}

\section{Zum Erkenntnisstand über die Baugeschichte des ehemaligen Prämonstratenserinnen- klosters Rosa Coeli in Dolní Kounice. Fund eines romanischen Wohnobjektes unter dem Bau des Barockkonvents}

Das ehemalige Prämonstratenserkloster Rosa Coeli steht am linken Flussufer der Jihlava am Südrand des Städtchens Dolní Kounice. Von dem Klosterkomplex sind die Außenmauern der Kirche, der einstöckige Kreuzgang und der sog. Barockkonvent erhalten geblieben. Laut dem Chronisten Gerlach wurde das Kloster Rosa Coeli in Dolní Kounice im Jahr 1181 von Wilhelm von Pulín gegründet. Zwei Jahre später sandte man Prämonstratenserinnen aus Louňovice in das Kloster. Man nimmt an, dass die Nonnen in bereits fertige Räumlichkeiten kamen. Wir wissen auch, dass die materielle Absicherung des Klosters anfänglich nicht gerade groß war und aus drei Dörfern und den Patronaten über sechs Kirchen bestand. Nachdem Ulrich von Dürnholz der letzte direkte Nachfahre Wilhelms - in der Schlacht bei Laa (1273) umgekommen war und wie wir wissen im Kloster begraben wurde, übernahm der böhmische König Wenzel II. die Gründungsrechte des Klosters. Der Überlieferung nach wurde das Kloster im Jahr 1423 bei den in Südmähren erfolgten hussitischen militärischen Operationen gebrandschatzt. Nach den Hussitenkriegen stabilisierte sich die wirtschaftliche Situation des Klosters allmählich, und bis zum Beginn des 16. Jahrhunderts zählte der Propst von Dolní Kounice zu den bedeutendsten Kirchenprälaten Mährens. In den darauffolgenden Jahrzehnten erlebte das Kloster jedoch wieder einen Niedergang, der dazu führte, dass es 1537 an Jiř́ Žabka von Limberg verkauft wurde. Anschließend wurden die Konventgebäude überwiegend zu wirtschaftlichen Zwecken genutzt. 1699 trat der damalige Eigentümer der Gutsherrschaft Ferdinand von Dietrichstein das ganze Areal an die Strahover Kanonie ab, die das Kloster wiederaufbauen wollte. Bald darauf wurde eine der Klosterkapellen eingeweiht, und parallel zur Renovierung der bestehenden Gebäude wurde der Barockkonvent errichtet. 1703 wurde die renovierte Kirche eingeweiht, die jedoch kurz danach wie auch die übrigen Gebäude von einem großen Brand heimgesucht wurde. Nach Beendigung des Wiederaufbaus setzte man ab 1729 im Kloster zwei Strahover Verwalter ein, was bis zum Jahr 1808 andauerte, als die Prager Prämonstratenser das Kloster wieder an die Familie Dietrichstein abtraten.

In den Jahren 1990 bis 1993 wurde das Kloster zum Gegenstand von Geländeuntersuchungen, deren Ergebnis die Aufstellung einer Hypothese über eine romanische Basilika war, deren Außenwände teilweise in den Außenmauern des heutigen einstöckigen Kreuzganges erhalten geblieben sind. Im Ostflügel wurden unter der Konventkapelle St. Johannes der Täufer die Fundamente eines romanischen Chorraums freigelegt. Weitere Umbauten des Klosters fallen erst in den Verlauf des 13. und 14. Jahrhunderts. Die Verfasser des vorliegenden Beitrags identifizierten entgegen älteren Annahmen im Rahmen des Erdgeschosses des Kreuzganges einige Mauerwerksabschnitte aus dem 13. Jahrhundert.

Bei den die Grabung begleitenden Aushüben zur Trockenlegung des Mauerwerks an der West- und Ostaußenwand des Barockkonvents und im Innenraum seines Südteils wurden bei der Tieferlegung des Fußbodenniveaus Mauerwerksüberreste von mehreren Bauphasen der untergegangenen mittelalterlichen Klostergebäude entdeckt, deren Existenz unbekannt war.

Im Rahmen einer archäologischen Rettungsgrabung wurden die Fundamente eines ausgedehnten romanischen Baus freigelegt (erste Bauphase). Das Objekt hatte die Ausmaße eines länglichen einflügeligen Traktes, der im gesamten Grundriss unterkellert war. Das $0,9 \mathrm{~m}$ starke oberirdische Außenmauerwerk wurde aus unregelmäßig bearbeiteten Quadersteinen im Läuferverband angelegt und mit feinem grauen Kalkmörtel verbunden, während der Mauerkern lediglich aus mit Mörtel ausgegossenen Steinen bestand. Unter dem Geländeniveau wurde das Mauerwerk auf beiden Seiten um ein Vorfundament vergrößert. Der Bau war über die gesamte, fast $110 \mathrm{~m}^{2}(17,0 \times 6,4 \mathrm{~m})$ betragende Fundamentfläche unterkellert. Die erhalten gebliebene Höhe der oberirdischen Mauerwerksteile war in keiner der Sondiergrabungen höher als 0,3 m. 
Gegenüber dem damaligen Gelände war das Souterrain ca. 2,3 m im Untergrund eingetieft. Im Rahmen der zweiten Bauetappe wurde das Souterrain teilweise verfüllt und der Fußboden des Erdgeschosses wurde auf das Gehniveau des umliegenden Geländes fixiert. Im Westteil des Objekts wurden im damaligen Interieur Querwände eingefügt, die zwei kleine, neu entstandene Keller abgrenzten. Der gesamte im 13. Jahrhundert erfolgte Umbau des Objektes wurde offenbar durch eine Änderung der Bedürfnisse hinsichtlich seiner Funktion hervorgerufen, möglicherweise wurde der Westteil als Küche benutzt. Parallel zu diesem Umbau erfolgte in der nächsten Umgebung der Bau neuer Konventgebäude. Das Objekt wurde bis zu seinem Untergang Ende des 17. Jahrhunderts noch mehrfach umgestaltet (3. bis 5. Bauetappe).

Eine grundlegende, durch die Grabung aufgeworfene Frage ist die Interpretation des Objektes. Als primäre Interpretation bietet sich die Möglichkeit an, dass wir hier das älteste Bauwerk des Konvents vor uns haben. Im Hinblick auf die Lage des Objektes gegenüber der angenommenen Kirche dürfte es sich dem traditionellen Schema der Benediktiner nach um das Refektorium handeln (vgl. z.B. Binding - Untermann 2001, 49-74). Es könnte auch ein Mehrzweckbau gewesen sein, der in der ersten Existenzphase des Konvents die Funktionen eines Schlafraums, Refektoriums und Kapitelsaales in sich vereinte (Untermann 1996, 233). In beiden der genannten Fälle wäre die Unterkellerung des gesamten Raumes jedoch sehr ungewöhnlich. Es besteht noch die Möglichkeit, den Bau - ähnlich wie im Falle des romanischen Palasgebäudes in der Benediktinerabtei in Třebíč - als alte Probstei zu interpretieren, jedoch wäre das Objekt für eine solche Nutzung äußerst ungünstig inmitten der künftigen Gebäude des Frauenkonvents gelegen. Die für Männer und Frauen bestimmten Konventteile waren im Rahmen der Klausur das ganze Mittelalter über strikt voneinander getrennt.

Im Zusammenhang mit der Suche nach einer Antwort bezüglich der ursprünglichen Funktion des freigelegten Baus kehren wir zur Hypothese von einer romanischen Klosterbasilika zurück (zu dieser Interpretation siehe oben). Die Struktur des von uns freigelegten, mit feinem grauen Kalkmörtel verbundenen Quadersteinmauerwerks des romanischen einflügeligen Traktes entspricht nicht der Technik, mit der die Nordwand des Kreuzgangs gemauert worden war, die als Mauerwerksüberrest des Schiffs der ehemaligen Basilika angesehen wurde. Im Mauerwerk der Nordwand des Kreuzgangs wurden die Quadersteine mit einem groben gelblichen Mörtel verbunden, der zwischen den einzelnen Steinen verstrichen wurde und mit einer durch Fugenritzung erzielten Quaderung versehen ist. Ähnliche Mörtel kennen wir ab dem zweiten Drittel des 13. Jahrhunderts auch aus Brünn. Das Relikt der Apsis, die als einziges eine ähnliche Mauerwerksstruktur aufweist, könnten wir hypothetisch als Apsis einer kleineren einschiffigen Kirche ansehen (?), die als Eigenkirche interpretiert werden könnte. Dadurch gelangen wir zu einer Hypothese, die voraussetzt dass das Bauwerk bereits in der Zeit vor dem Kloster errichtet worden war, mit dem Konvent primär nichts gemein hatte und erst anschließend in ihn eingegliedert wurde.

Im Hinblick auf den einfachen Grundriss und offenbar auch auf die Umfriedung des Areals mit einem Graben (siehe Sondiergrabung S4) können wir das Bauwerk mit einer gewissen Vorsicht als Sitz des Klostergründers Wilhelm von Pulín ansehen. Er könnte den Prämonstratenserinnen auch eine kleine Eigenkirche übergeben haben, von welcher der südlich von seinem Sitz gelegene Chorraum (vgl. oben romanische Basilika) freigelegt wurde. Dann hätten wir hier einen Sitz vor uns, der ein Gehöft darstellt, wie wir es in Böhmen beispielsweise aus Týnec nad Sázavou kennen - zweite Bauetappe (zusammenfassend z.B. Varhaník 2007), Bedřichův Světec (Klápště 1994, 31-38; 2005, 113-118), Chvojen (Hejna 1983, 368n) oder Vroutek (Hejna 1977, 69-70).

Mgr. Marek Peška, Archaia Brno, o.p. s., Bezručova 15/78, 60200 Brno, Česká republika, mpeska@archaiabrno.cz

David Merta, Archaia Brno, o.p.s., Bezručova 15/78, 60200 Brno, Česká republika, dmerta@archaiabrno.cz 
